\title{
The Growing Importance of Secondary Market Activities for Open-end Real Estate Fund Shares in Germany
}

\author{
Philipp Gerlach ${ }^{1}$ (D) $\cdot$ Raimond Maurer $^{1}$
}

Received: 1 September 2018 / Accepted: 21 December 2019 / Published online: 22 January 2020

(C) The Author(s) 2020

\begin{abstract}
Shares of open-end real estate funds are typically traded directly between the investor and the fund management company. However, we provide empirical evidence for the growth of secondary market activities, i.e., the trading of shares on stock exchanges. We find high trading levels in situations where the fund management company suspends the issue or redemption of shares. Shares trade at a discount when the fund management company suspends the redemption, whereas shares trade at a premium when the fund management company suspends the issue. We also find evidence that secondary market trading activity is increasing since German regulation introduced a minimum holding period and a mandatory notice period for openend real estate funds.
\end{abstract}

Keywords Open-end real estate funds · Secondary market · Trading restrictions · NAV-price-spread

JEL Classification $\mathrm{G} 11 \cdot \mathrm{G} 28 \cdot \mathrm{G} 29$

\section{Introduction}

Open-end real estate funds (OREFs) are collective investment undertakings managed by fund management companies that raise capital from a large number of investors

P. Gerlach

gerlach@finance.uni-frankfurt.de

R. Maurer

maurer@finance.uni-frankfurt.de

1 Finance Department, Goethe University, Theodor-W.-Adorno-Platz 3, 60323 Frankfurt am Main, Germany 
in order to form a diversified portfolio of income-generating properties. In contrast to closed-end funds, which close the issue of additional shares once a desired capital amount is collected, open-end funds remain open for further capital inflows. Therefore, fund management companies issue and redeem shares upon request, typically on a daily basis. Once every trading day, the fund management company determines the net asset value per share, at which all issue and redemption requests are then executed. The net asset value per share is calculated by dividing the total net asset value of the fund by the total number of shares outstanding, whereby the property values are based on appraisals by independent experts. When purchasing OREF shares from the fund management company, investors pay a front-end load of typically $5 \%$ and, in some cases, also a back-end load when redeeming their shares.

In addition to the direct purchase and redemption of shares via the fund management company, investors can trade OREF shares with each other on regulated secondary markets. In Germany, the Hamburg Stock Exchange became the first to launch the trading of funds in 2002, followed by all major German stock exchanges and electronic trading systems. ${ }^{1}$ The trading volume of fund shares has increased since the introduction of exchange trading in Germany. On the Hamburg Stock Exchange, for example, trading of fund shares increased from $€ 177 \mathrm{~m}$ in 2003 to $€ 930 \mathrm{~m}$ in 2017 , of which $€ 78.6 \mathrm{~m}$ in 2003 and $€ 543.9 \mathrm{~m}$ in 2017 were attributable to the trading of OREF shares.

The share price on the stock exchange reflects the current market expectation on the future development of the fund and may therefore deviate from the net asset value per share. In contrast to the direct purchase of OREF shares from the fund management company, no front-end load is charged for the purchase of OREF shares on the stock exchange. Commonly, the market price equals the net asset value per share plus a bid-ask spread. This spread represents the implicit costs for buying shares on the stock exchange and is commonly less than $1 \%$. In addition to the spread, investors pay direct transaction costs, such as broker's commissions and order fees. Trading OREF shares on the stock exchange offers investors several advantages. Depending on the invested amount and the current bid-ask spread, buying shares on the stock exchange can be cheaper than purchasing the shares directly from the fund management company. In addition, it is possible to trade shares on the stock exchange on a continuous basis during the trading day. Most importantly, even if the fund management company restricts the regular issue and redemption process, investors can still trade OREF shares on the stock exchange.

Two liquidity crises have hit German OREFs: The first was in 2005-2006, and the second was in 2008-2009. The crises were triggered by massive and simultaneous redemption requests by shareholders. As a result, several OREFs suspended the redemption of shares, and some of the funds finally announced their liquidation. During the redemption suspension and liquidation phase, investors were only able to trade shares of the distressed funds on the stock exchange. After the two liquidity crises, German legislation introduced a minimum holding and notice period to pre-

\footnotetext{
1 The Berlin Stock Exchange in 2003, the Düsseldorf Stock Exchange in 2005, the Munich Stock Exchange, the Frankfurt Stock Exchange, Lang \& Schwarz, the Stuttgart Stock Exchange, and Quotrix in 2006, XETRA in 2008 and, finally, the Tradegate Exchange in 2010.
} 
vent future liquidity crises. In contrast to the two preceding liquidity crises, several OREFs suspended the issue of additional shares in 2016-2017 because they could not profitably invest incoming capital. During the issue suspension, investors were again limited to buying shares on the stock exchange.

The present paper contributes to the literature on OREFs, studying how the restriction of the regular issue and redemption process impacts secondary market activities for OREF shares. Trading of OREF shares on secondary markets has thus far been neglected in the literature (Maurer et al. 2004; Focke 2006; Bannier et al. 2008; Fecht and Wedow 2014; Weistroffer and Sebastian 2015). For example, Bannier et al. (2008) state that secondary "markets are not very liquid and the trading of shares on these exchanges will typically be suspended in crisis situations" (Bannier et al. 2008, p. 9). Our research points to the opposite conclusion, i.e., there is substantial trading on secondary markets, particularly in crisis situations. First, this paper studies restrictions on an individual fund level, i.e., funds that temporarily suspend the issue or redemption of shares, as well as funds that are being liquidated. Second, this paper studies restrictions at an aggregate level, i.e., the impact of the introduction of the minimum holding period together with the notice period. Piecewise linear and polynomial regressions show that more shares are traded on the secondary market when the fund management suspends the issue or redemption process or when a fund is in liquidation. In addition, secondary market trading increases at a higher rate following the introduction of the minimum holding and notice periods. The results in this paper also show that OREF shares are traded at a discount on secondary markets when the fund management suspends the redemption of shares or when the fund is being liquidated. On the contrary, shares are traded at a premium on secondary markets when the fund management suspends the issue of additional shares.

The existing literature on OREFs can be divided into two areas. The first literature field documents the major characteristics of OREFs. For example, Maurer et al. (2004) estimate the historical short and long-term return characteristics, finding that OREFs exhibit moderate and stable returns with low correlations to equity markets and moderate correlations to bond and money markets. Focke (2006) describes the legal construction and the historical development of German OREFs. The author concludes that the main benefits of OREFs are risk diversification, low minimum investment volumes, and daily tradability of shares. Maurer et al. (2012) analyze the role of OREFs in multi-asset retirement withdrawal plans. They find that OREFs play an important role in diversifying portfolios; however, potential redemption suspensions and devaluations significantly reduce the optimal fraction of OREFs in retirement portfolios. Downs et al. (2016) document a convex flow-performance relationship for OREFs, i.e., investors buy shares of funds that outperform their peers while they are reluctant to sell shares of funds that underperform their peers.

The second literature field studies the liquidity crisis of OREFs. Sebastian and Tyrell (2006) emphasize that the open-end architecture provides an efficient instrument to discipline the fund managers and therefore can represent a more adequate solution to securitize real estate assets. Bannier et al. (2008) furthered the argumentation of the disciplining effect that the risk of liquidity runs has on the fund managers. However, the authors note that measures to reduce arbitrage opportuni- 
ties resulting from a staggered appraisal of the real estate assets may increase the resilience of OREFs. Fecht and Wedow (2014) stress that the mismatch of illiquid assets and liquid liabilities also bears the risk of investors withdrawing their funds prematurely because they expect other investors to do the same. They show that investors' expectations of the withdrawal decisions of other investors contributed substantially to the massive capital outflows during the liquidity crisis. To reduce the risk of a liquidity crisis, the authors suggest higher liquidity buffers and a separation of share classes for institutional and retail investors. Weistroffer and Sebastian (2015) provide empirical evidence that the real estate assets held by OREFs were likely to have been overvalued prior to the crisis. The authors conclude that their results support the view that the crisis was a fundamentally justified run. In a recent paper, Schnejdar et al. (2019) analyze the price-spread of OREFs that are in liquidation due to insufficient liquidity reserves. They show that macroeconomic and fundamental factors such as leverage ratio and liquidity ratio have an effect on the price-spread of OREFs in liquidation. We contribute to the existing literature, providing new information on the characteristics, i.e., the trading activity and market prices for OREF shares on the secondary market and how crisis situations such as the liquidity crisis affect the secondary market for OREF shares.

\section{Historical Background and Hypothesis Development}

\subsection{Historical Background}

Trading of OREF shares by construction is supposed to occur directly between investors and fund management companies. In situations where direct trading is restricted, investors may trade their shares on the secondary market. The following chapter outlines the historical events that led to restrictions on direct trading between investors and fund management companies. ${ }^{2}$

\subsubsection{Liquidity Crisis}

Since their inception in 1959, German OREFs had been able to satisfy all daily issue and redemption requests. However, in 2005 and 2006, there was a massive and simultaneous request by investors for a redemption of their shares in reaction to public rumors that the two fund management companies, Deutsche Bank and KanAm, would devaluate the real estate assets of their OREFs. The resultant massive capital outflows forced Deutsche Bank and KanAm to temporarily suspend the redemption of shares. Three years later, German OREFs faced an even more severe liquidity shortage. In the wake of the financial crisis, the entire branch of OREFs experienced massive outflows such that one-third were forced to temporarily suspend the redemption of shares. In the end, 18 OREFs announced their liquidation.

\footnotetext{
2 This study focuses on OREFs offered to the general public (Publikumsfonds) and omits real estate funds that are only available to institutional clients (Spezialfonds). The latter possess different fund characteristics and are subject to different regulatory requirements.
} 


\subsubsection{Regulatory Changes}

At the time of the first liquidity crisis, few rules on the suspension of share redemptions existed. These rules stipulated that if there are insufficient liquidity reserves to satisfy all redemption requests, fund management may refuse the redemption of shares for a period specified individually in the contractual terms. If after the end of this period there are still insufficient liquidity reserves, fund management has to begin to sell assets at fair value. Fund management may suspend redemption until the asset sales, but no longer than one year after the refused redemption request. The one-year period can be extended by the contractual terms for an additional year. After the expiry of this period, the fund management company may lend fund assets to raise capital for the redemption of shares.

In December 2007, after the first liquidity crisis, the first formal rules on the issue suspension were introduced. These rules stipulated that the issue of shares must be suspended upon the risk of violating the $49 \%$ regulatory liquidity limit, or an individual limit specified in the contractual terms of the fund. In addition, the regulation introduced the possibility that the contractual terms of OREFs may state that the redemption of shares will be carried out only once a month in the event that the total redemption requests exceed a specified limit. In such a case, redemptions must be made by an irrevocable declaration subject to a minimum notice period of up to 12 months.

In April 2011, after the second liquidity crisis, more details on the process of redemption suspensions were amended. These amendments required that, in the exceptional event of insufficient liquidity reserves to satisfy all redemption requests, the fund management must suspend the redemption of shares. If, even after six months, the liquidity reserves are insufficient, fund management must sell assets on fair value terms and continue to refuse to redeem shares for up to six more months. If, 12 months after the suspension of redemption, the liquidity reserves are still not sufficient, the fund management must continue to refuse share redemptions and sell fund assets. However, the sales price can now fall up to $10 \%$ below the appraisal value. If, 24 months after the suspension of redemption, the liquidity reserves are still insufficient, fund management must continue to refuse to redeem shares and sell fund assets, and the sales price may now be up to $20 \%$ lower than the appraisal value. Finally, if even 30 months after the redemption suspension, the liquidity reserves are insufficient to satisfy all redemption requests, the fund management company loses its right to manage the distressed OREF. A fund management company that has officially announced the termination of its fund is obliged to sell all fund assets until the termination becomes effective. From these asset sales, a semi-annual payment is to be made to shareholders. In addition to the process during the exceptional events of insufficient liquidity reserves, a minimum holding period of 24 months and a mandatory notice period of 12 months for share redemptions over $€ 30,000$ was introduced.

As of July 2013, the process on the redemption suspension was revised again. According to the new regulations, in the exceptional event of insufficient liquidity reserves to satisfy all redemption requests, the fund management must suspend the redemption of shares and immediately begin to sell fund assets on fair value 
terms. If the liquidity is insufficient 12 months after the redemption suspension, the fund management company must continue to refuse the redemption and sell fund assets. The sale price may now be up to $10 \%$ lower than the appraisal value. If, 24 months after the suspension of redemption, the liquidity reserves are still insufficient, the fund management may sell assets up to $20 \%$ lower than the appraisal value. Finally, if even 36 months after the redemption suspension, the liquidity reserves are insufficient, the fund management company loses its right to manage the distressed OREF. In addition to the revision of the process during redemption suspension, the $€ 30,000$ allowance was abrogated to a general minimum holding period of 24 months and a mandatory notice period of 12 months.

\subsubsection{Issue Stops}

In 2016 and 2017, several OREFs suspended the issue of additional shares. On the one hand, there was a high demand for OREF shares, while on the other hand, there were few profitable investment opportunities for the fund managements to invest their incoming capital in because the real estate markets were at a very high price level. In addition, the interest rates remained at a level around zero; therefore, additional capital could not be held as liquidity reserves because the low interest rate diluted the overall fund performance.

\subsubsection{Liquidity Management}

Fund management companies have also developed different approaches to control fund liquidity. In contrast to regulatory requirements, these processes primarily aim to ensure that additional incoming capital can be invested profitably. The liquidity processes of fund management companies can be divided into three approaches. The first approach represents the most open fund structure. OREFs following this approach issue and redeem shares on a daily basis. Only in situations when the fund liquidity exceeds or falls below a critical threshold, will the issue or redemption of shares be temporarily suspended. The second approach also represents an open structure but it limits the number of shares to be issued. Depending on the expected future developments of real estate markets, funds following this approach will define contingents of shares to issue over the following months. The third approach is the most restrictive. Funds following this approach are generally closed to additional capital inflows. If a liquidity requirement arises over the course of time, e.g., for a planned acquisition or the redevelopment of a property, the fund management company announces a "cash call". From the date of the cash call, the fund issues additional shares until the targeted capital amount has been collected. Having successfully collected the required amount of capital, the fund will again be closed.

\subsection{Hypothesis Development}

The aim of the present paper is to estimate the secondary market trading activities for OREF shares. The empirical study examines the impact of temporary redemp- 
tion or issue suspensions and a permanent liquidation of a fund on the trading of OREF shares on secondary markets. In addition, the study investigates whether the introduction of a minimum holding period together with a notice period significantly affects secondary market activities for OREF shares.

One major characteristic of OREFs is that their shares can be directly traded between investors and the fund management company. In a direct trade between the investor and the fund management company, the price per share depends solely on the total net asset value of the fund and the number of outstanding shares, whereas the price on the secondary market is determined by supply and demand. If investors can trade their shares directly with the fund management company, they will not accept a premium when purchasing or a discount when selling fund shares on the secondary market. Therefore, in times when trading with the fund management company is unrestricted, the secondary market price should equal the net asset value per share. In times when the fund management company is not redeeming fund shares, there may be investors who are willing to sell their shares, even at a discount, on the secondary market. Conversely, investors may be willing to pay a price premium to buy fund shares on the secondary market if the fund management company has suspended the issue of additional shares.

\subsubsection{Issue Suspension}

In the event that the fund management is unable to profitably invest the capital inflow, the fund management company will suspend the issue of shares. Potentially, there will be investors who are willing to buy OREF shares on the secondary market for a price above the net asset value per share; at the same time, there will be shareholders who are willing to sell their shares at a premium.

Hypothesis 1 The secondary market trading of open-end real estate funds is higher when the issue of shares is suspended.

Hypothesis 2 The secondary market price is above the net asset value per share when the issue of shares is suspended.

\subsubsection{Redemption Suspension}

In the event of excessive redemption requests, the fund management company will suspend the redemption of shares. The only remaining option will be to sell the shares on the secondary market, stimulating a general increase in the trading volumes on secondary markets. In addition, with the beginning of the redemption suspension, the fund management must sell real estate assets, potentially below fair value, to provide enough liquidity to satisfy all redemption requests. Such an unexpected suspension event causes a high level of uncertainty among the shareholders concerning the future status of the fund, i.e., whether the fund management will be able to provide enough liquidity to satisfy all redemption requests or whether the management will be forced to liquidate the fund. These suspension events attract the attention of the general public and the media. During past redemption suspensions, there were substantial 
debates in the media on the reliability of OREFs, which amplified the uncertainty among shareholders. Due to the uncertainty regarding the future status of the fund, there will be shareholders who are willing to sell their shares on the secondary market at a discount because they fear that the fund management will have to sell real estate assets below fair value. Conversely, there will also be market participants who believe that the public debate on the reliability of OREFs is exaggerated and that the secondary market price decrease is mainly a result of shareholder overreaction. These market participants are convinced that the current secondary market price is too low compared to the true value of the fund's property portfolio; therefore, they will consider shares of distressed OREFs a beneficial investment opportunity.

Hypothesis 3 The secondary market trading of open-end real estate funds is higher when the redemption of shares is suspended.

Hypothesis 4 The secondary market price is below the net asset value per share when the redemption of shares is suspended.

\subsubsection{Liquidation}

In the event that the fund management is unable to provide enough liquidity to satisfy all redemption requests, the fund must be liquidated and property sale revenues are paid out to its shareholders. Once the liquidation of the fund is officially announced, the fund management company will not issue new shares nor redeem existing shares. Investors will only be able to buy or sell the shares on the secondary market, again resulting in an increase in the secondary market trading volume. With the official liquidation announcement there is no more uncertainty regarding the future status of the fund. Instead, it is clear that the invested capital is now bound for a longer period of time and will only be paid out gradually. The property sale revenues, however, are unknown. Now that the entire real estate portfolio will be sold on the market, any existing overvaluations of its property holdings become evident. In addition, the fund management may have to accept considerable price discounts in order to be able to sell the properties at short notice. Like in the event of a temporary redemption suspension, there will be shareholders who are willing to sell their shares at a discount on the secondary market because they either need the money immediately or fear that the real estate assets will be sold at a substantial discount. However, there will also be market participants who are willing to see the iterative liquidation process through and are convinced that the fund management will be able to sell the properties without a substantial discount. They believe that the sum of future payments per share will exceed the current secondary market price and that buying these shares on the secondary market is therefore a profitable investment.

Hypothesis 5 The secondary market trading of open-end real estate funds is higher when the fund is being liquidated.

Hypothesis 6 The secondary market price is below the net asset value per share when the fund is being liquidated. 


\subsubsection{Minimum Holding and Notice Periods}

Since the introduction of the minimum holding period together with the notice period in April 2011, the redemption for newly issued shares has become less flexible. There may be investors who are willing to sell their shares on the secondary market, even at a discount, instead of waiting out the notice period. Considering that the number of OREF shares increases over time due to additional capital inflows and property revenues that are typically distributed to shareholders in the form of additional shares, the trading of OREF shares on the secondary market is expected to steadily increase after the regulatory change. With an increasing number of shares offered on the secondary market, the market price should decline.

Hypothesis 7 The secondary market trading of open-end real estate funds has been increasing at a faster rate since the introduction of the notice period.

Hypothesis 8 The spread between the net asset value per share and the secondary market price has been increasing since the introduction of the notice period.

\section{Methodology}

\subsection{Data}

We conduct an empirical analysis of the secondary market activities for a sample of German open-end real estate funds over the January 2003-October 2017 period. Our dataset combines information from different data sources. Secondary market data is collected from the two websites www.ariva.de and www.finanzen.net. We use these two websites because they contain different sets of funds. The website www.ariva. de provides daily information on the trading of OREFs, separately for different exchanges in Germany. The data includes market prices (high/low and first/last), numbers of traded shares, and traded volume in fund currency. The website www. finanzen.net also provides daily information on the trading of OREFs separately for different exchanges in Germany. The data includes market prices (high/low and first/ last) and number of traded shares. The daily numbers of traded shares are aggregated by adding together the numbers of traded shares for each OREF across the regional exchanges. Table 1 summarizes the information about OREF trading activities on the different exchanges. In Germany, OREFs are traded on ten exchanges, among which the Frankfurt, Hamburg, and Stuttgart exchanges dominate. These three exchanges account for $89 \%$ of the total number of traded shares.

In the following analysis, we use relative trading volumes that are calculated as the ratio of the traded number of shares relative to the total shares outstanding. This fraction is expressed as a percentage, i.e., multiplied by 100 . The German Investment and Asset Management Association (BVI) provided us with the monthly total net assets under management. To match the monthly information on the total net assets under management with the daily secondary market data, we use a linear interpolation technique. 
Table 1 Listing of stock exchanges in the sample

\begin{tabular}{lllllll}
\hline & Trades & \multicolumn{2}{l}{ Daily Traded Shares } & & & Traded Shares \\
& & Mean & Std & Min & Max & \\
\hline Berlin & 15,316 & 3814 & 7055 & 5 & 240,125 & $13,848,447$ \\
Düsseldorf & 14,788 & 4217 & 9505 & 1 & 409,060 & $13,250,045$ \\
Frankfurt & 28,220 & 15,863 & 14,158 & 60 & 263,885 & $46,144,444$ \\
Hamburg & 43,661 & 60,958 & 60,213 & 103 & 536,453 & $229,934,798$ \\
Lang \& Schwarz & 33 & 245 & 240 & 1 & 916 & 4410 \\
München & 11,753 & 1985 & 2340 & 3 & 28,408 & $5,745,319$ \\
Quotrix & 155 & 679 & 1076 & 2 & 8683 & 93,075 \\
Stuttgart & 26,865 & 23,214 & 196,280 & 20 & $10,280,838$ & $64,720,598$ \\
Tradegate & 14,848 & 6087 & 9633 & 106 & 80,901 & $11,218,656$ \\
Valora Effekten Han- & 2 & 430 & 476 & 93 & 766 & 859 \\
del & & & & & & \\
\hline
\end{tabular}

This table reports summary statistics on the trading of open-end real estate funds for the exchanges in Germany over the period January 2003-October 2017. The first column (Trades) reports the total number of trades. The second column (Daily Traded Shares) reports the average, standard deviation, minimum, and maximum of traded shares per day. The third column (Traded Shares) reports the total number of traded shares in the observation period

We estimate the daily secondary market price as the simple mean of the high and low price. In those cases where no high or low price is provided, the daily first and last price is used. The daily secondary market price for each OREF is then aggregated using the simple average across the different exchanges. ${ }^{3}$ Information on the daily net asset value per share is obtained from the website www.ariva.de. For three OREFs, the daily net asset values per share are obtained from Thomson Reuters Datastream because www.ariva.de does not provide this information.

Table 2 lists the OREFs covered in our sample combined with information on the inception date, liquidity management approach, and assets under management (AuM) as of October 31, 2017. In total, our sample covers 31 funds. The largest three (six) funds with euro currency manage $49 \%$ (78\%) of the net assets of all German OREFs. To manage liquidity, three funds have implemented a cash call approach, three funds define contingents of shares that will be issued over the following months, and the remaining 25 funds work with temporary issue suspensions.

Information on the fund suspensions and liquidations is provided by the website of the German Bundesanzeiger (www.bundesanzeiger.de) and the fund management companies themselves. The Bundesanzeiger is the official gazette of the German federal authorities. It is issued by the Federal Ministry of Justice. By law, fund management companies must announce the suspension of share redemptions and the liquidation of a fund in the Bundesanzeiger. In addition, the suspension of share redemptions and liquidations must be published in the annual or semi-annual fund

\footnotetext{
3 In an unreported analysis, we aggregate the daily secondary market price for each OREF by the weighted prices across different exchanges. The weight for each exchange is the trading volume in numbers of traded shares relative to the overall trading volume in numbers of traded shares. The weighted market price gives the same regression results as the unweighted market price.
} 


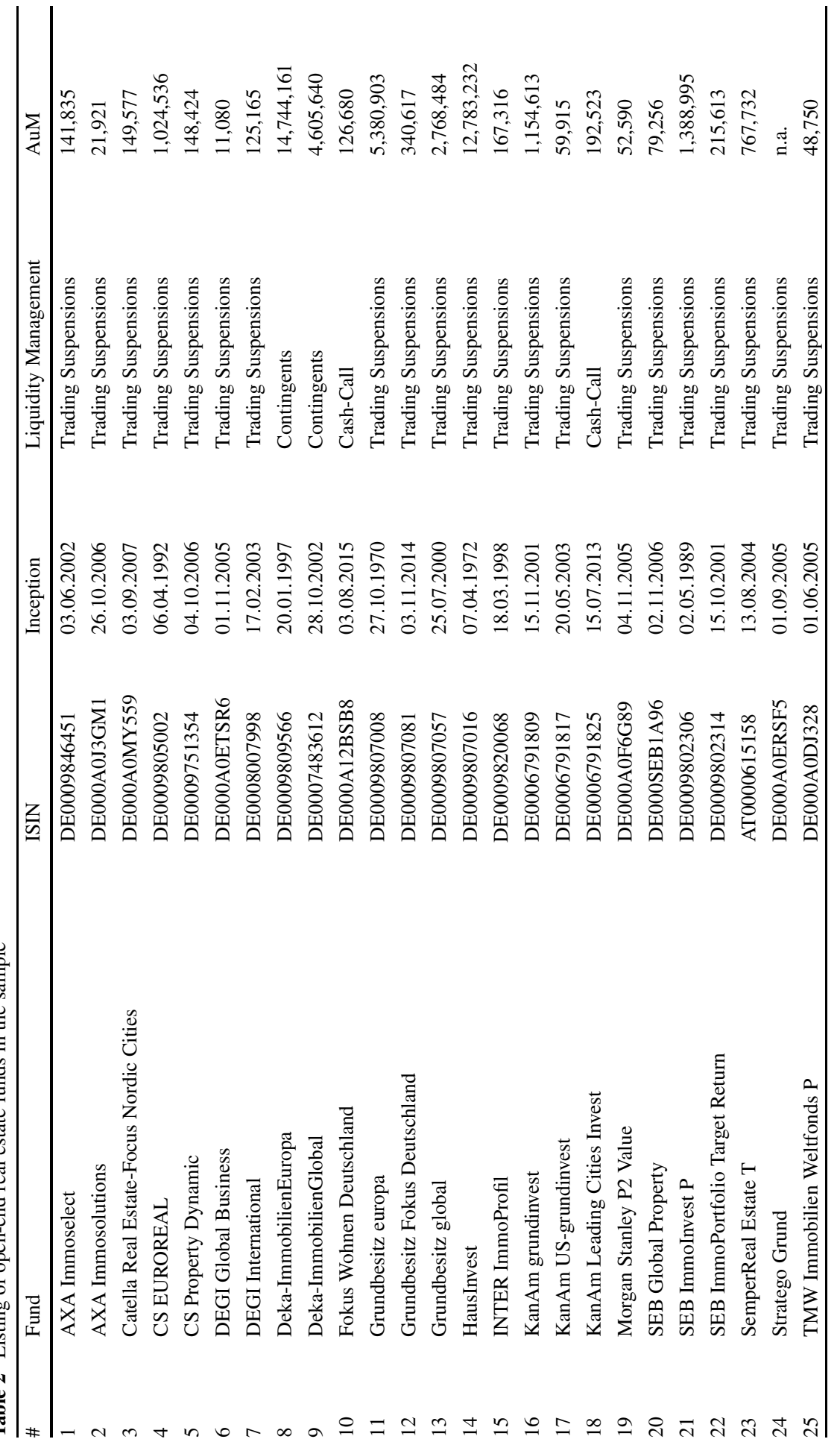




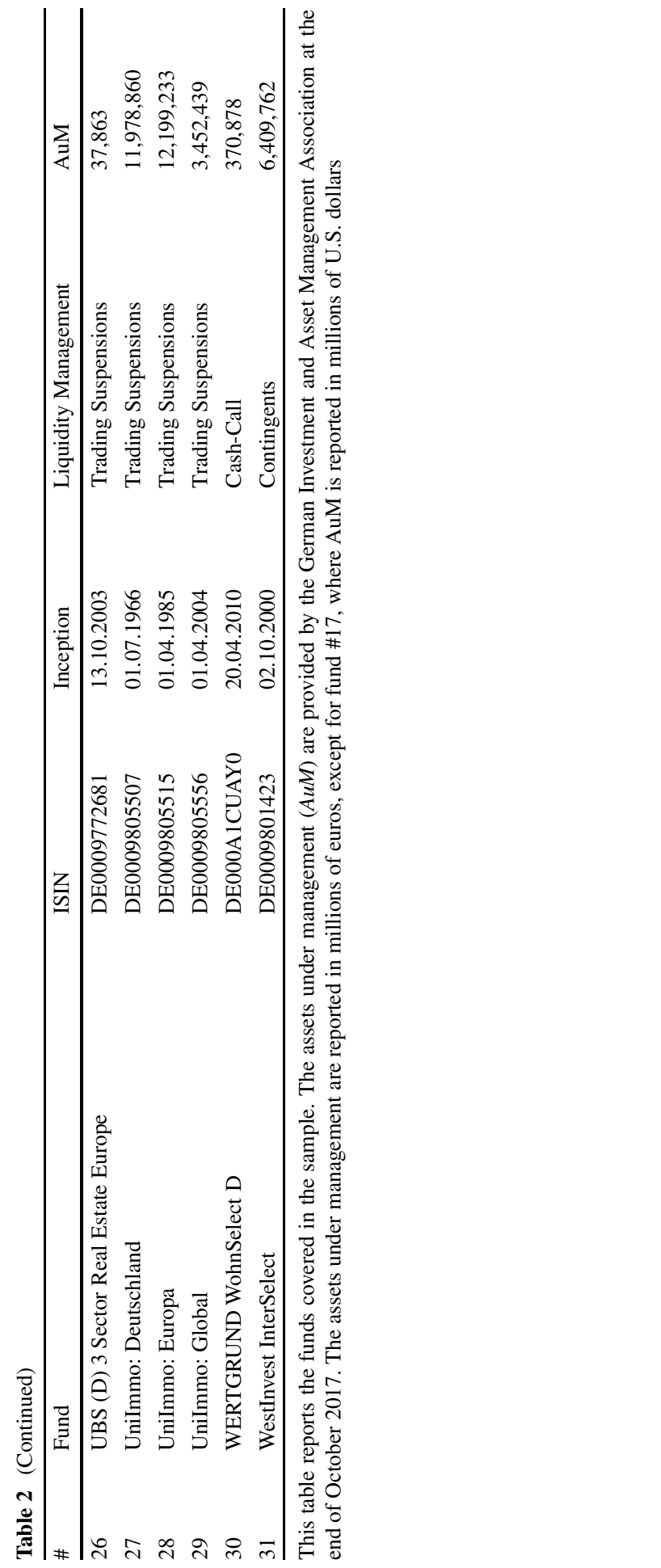


reports. For fund liquidations, the official announcement date must take place prior to the final notice date due to the required notice period. In the following, we report the date on which the fund management announced the fund's liquidation. Fund management companies are only obliged to report the temporary suspension of redemptions and fund liquidations in the Bundesanzeiger. Therefore, we searched for information on the issue suspension of additional shares in the annual reports of the fund management companies.

Fig. 1 shows the daily numbers of shares traded on the secondary market relative to the total numbers of shares outstanding multiplied by 100 , together with the periods in which the direct trading with the fund management company is restricted. Due to space limitations, we depict only the 21 funds with the most observations of trades on the secondary market. The historical numbers of OREF shares traded on the secondary market show three noticeable features. First, it is interesting that the trading volume of OREFs that are not under liquidation has increased linearly in recent years. Second, for most funds, the numbers of shares traded on the secondary markets is higher during the official issue/redemption suspension and during the liquidation phase. An illustrative example is given by the historical trading volume of SEB ImmoInvest P. Lastly, there are some peaks in the historical trading volumes for funds that have not suspended the issue/redemption of shares and are still active. For example, the trading volume of hausInvest shows a peak in 2009/2010.

Fig. 2 shows the daily net asset value per share and the secondary market price of German OREFs combined with the liquidation phases and the temporary issue and/or redemption suspensions. Again, we illustrate only the 21 funds with the most observations of trades on the secondary market.

In general, for funds without sales contingents, the market price tends to equal the net asset value per share when the issue and redemption process is not suspended. However, if the fund management restricts the issue or the redemption process, the market price can deviate significantly from the net asset value per share, most obviously during times when the fund management suspends the redemption or is being liquidated. In addition, it is interesting to see that the spread between the net asset value per share and the market price increases the longer the redemption suspension lasts. A potential reason for the widening price-spread is the increasing risk that the fund is not able to provide enough liquidity and therefore has to be liquidated. On the contrary, the price-spread decreases over the course of the liquidation phase. This might be due to the fact that the net asset value decreases and therefore the uncertainty of the revenue of the remaining assets decreases. In the event that a fund suspends only the issue of additional shares, the market price is above the net asset value per share, except for grundbesitz Europa. Lastly, for funds following a contingent approach such as Deka-ImmobilienEuropa and Deka-ImmobilienGlobal, the market price generally shows a higher variation around the net asset value per share.

To get a first impression how secondary markets react to different direct trading suspensions, we portray the development of the price-spread and trading volume shortly before and after the day on which a suspension is announced. In detail, for each suspension event, we select the secondary market data of the preceding six and the subsequent three weeks. These individual series of daily price-spreads and trading volumes are then averaged across the same types of suspension event. 

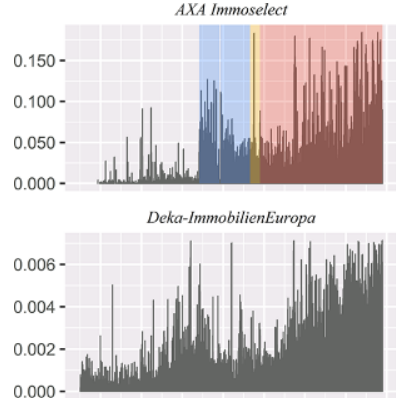

0.000

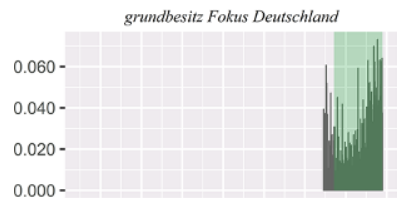

$0.000-$
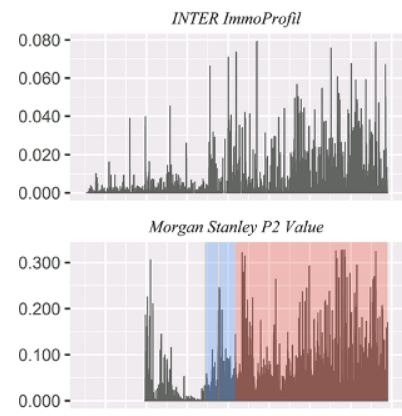

TMW Immobilien Weltfonds $P$

0.080

0.060

$0.040-$

$0.020-$

$0.000-$

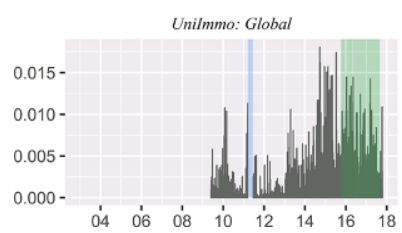

CS EUROREAL

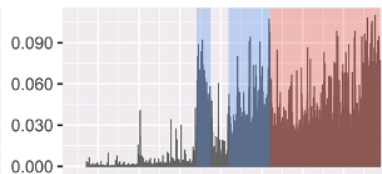

Deka-ImmobilienGlobal

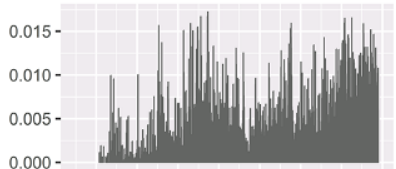

$0.000-$

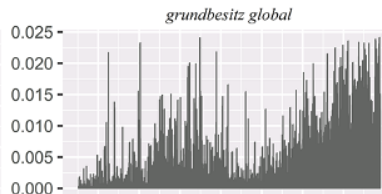

$0.000-$

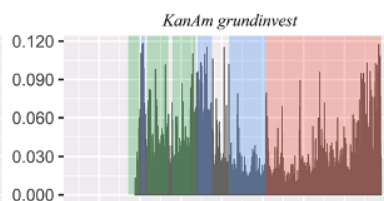

$0.000-$

SEB Immolnvest $P$

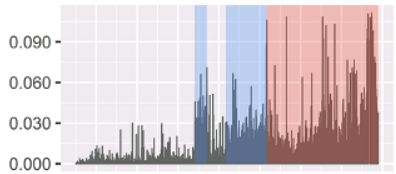

Unilmmo: Deutschland

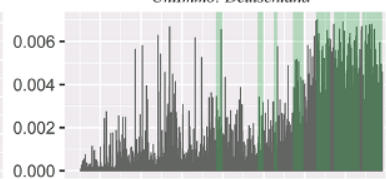

WERTGRUND WohnSelect D

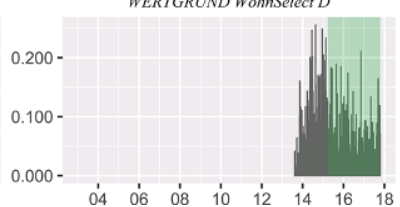

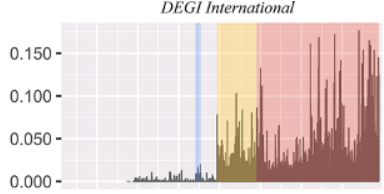

grundbesitz europa

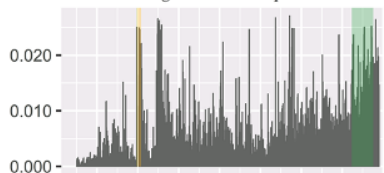

hausInvest

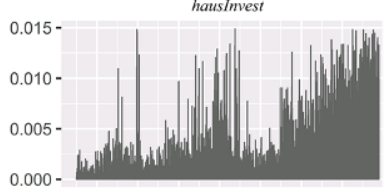

KanAm US-grundinvest

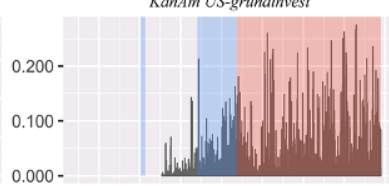

$0.000-$

SEB ImmoPortfolio Target Return

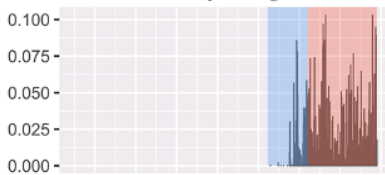

Unilmmo: Europa

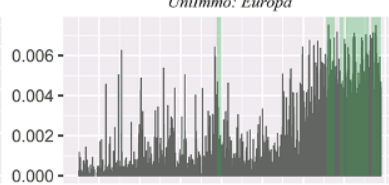

WestInvest InterSelect

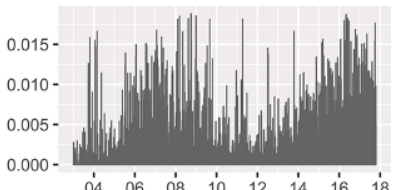

Fig. 1 Relative trading volume in percentage over time (This figure shows the daily numbers of shares traded on the secondary market relative to the total numbers of shares outstanding, multiplied by 100 , as well as temporary trading suspensions and permanent fund liquidations as announced by the fund management companies of German open-end real estate funds. The period in which the fund management suspends the issue of additional shares is highlighted in green, the redemption suspension is in blue, and the suspension of the issue and the redemption is in yellow. The period in which the fund is being liquidated is highlighted in red) 

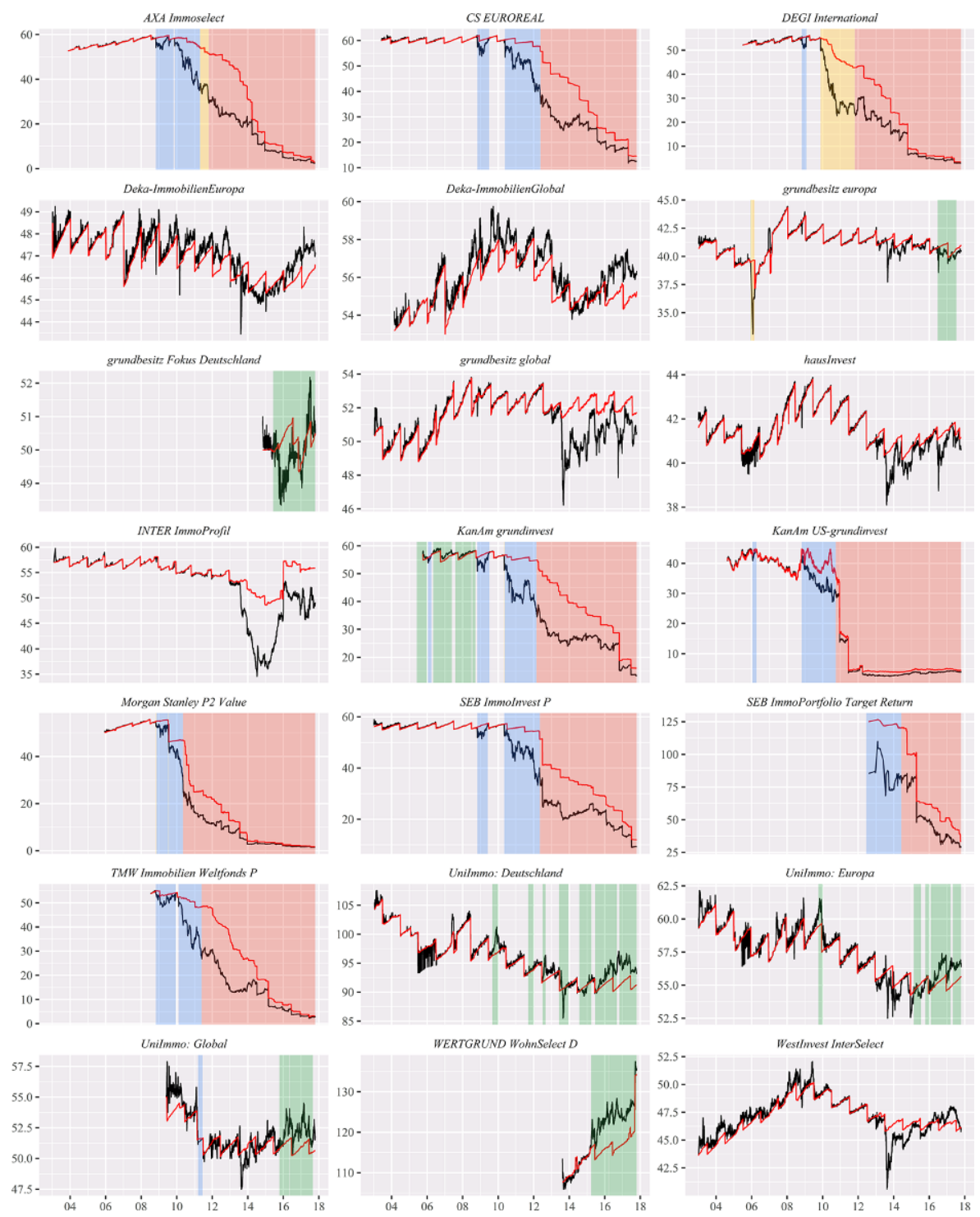

Fig. 2 Fund price development over time (This figure shows the net asset value per share (red line) and the secondary market price per share (black line) in the respective fund currency, as well as temporary trading suspensions and permanent fund liquidations as announced by the fund management companies of German open-end real estate funds. The period in which the fund management suspends the issue of additional shares is highlighted in green, the redemption suspension is in blue, and the suspension of the issue and the redemption is in yellow. The period in which the fund is being liquidated is highlighted in red) 


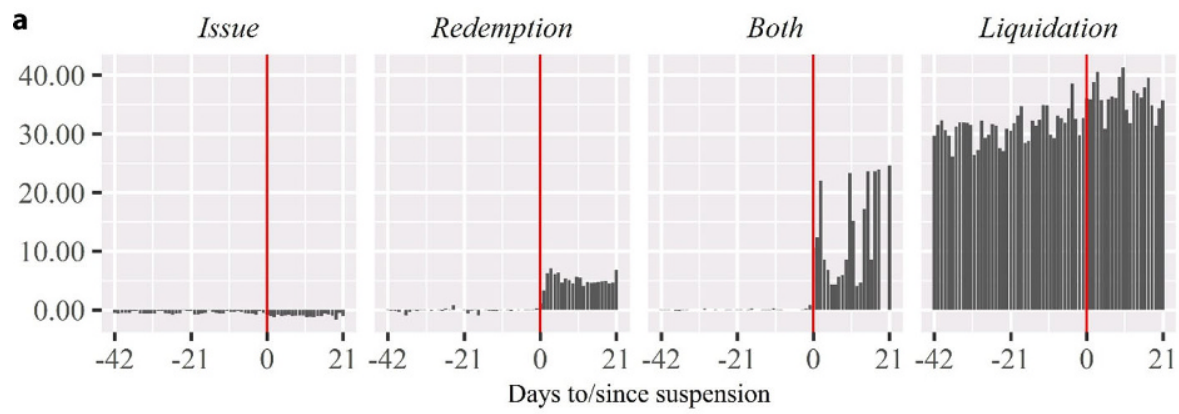

b

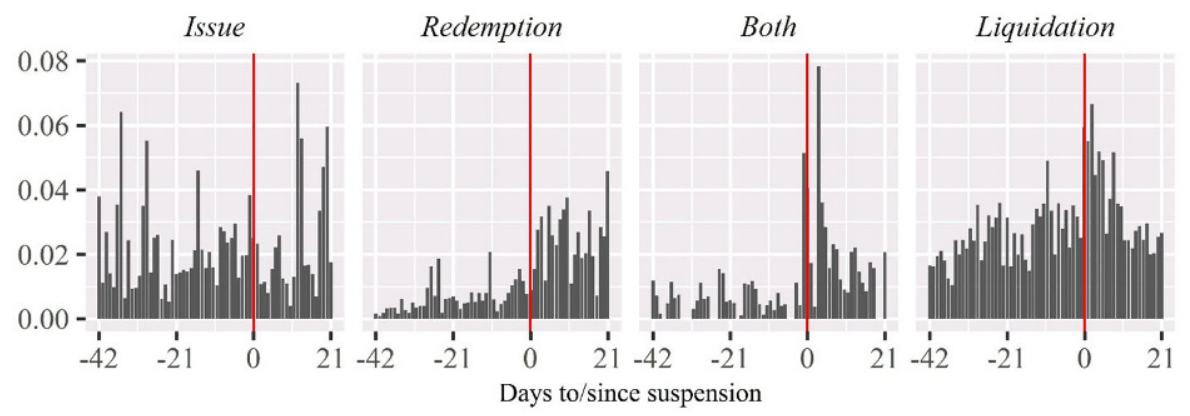

Fig. 3 Price-spread and trading volume around the suspension day in percentage. a Price-Spread. b Trading Volume (This figure shows the price-spread and trading volume around the day a suspension is announced. Presented are the averages of the individual suspension events. The price-spread is the difference between the net asset value per share and the secondary market price relative to the net asset value per share, multiplied by 100 . The daily trading volume is calculated as numbers of shares traded on the secondary market relative to the total numbers of shares outstanding, multiplied by 100 . The suspension events are: Issue if the fund has suspended the issue of new shares, Redemption if the fund has suspended the redemption of shares, Both if the fund has suspended the issue and redemption of shares, and Liquidation if the fund management has announced the liquidation of the fund)

However, we make the following two restrictions: First, we exclude those suspension events for which we can also observe any kind of suspensions in the preceding six weeks. Without this restriction, the secondary market trading before the respective suspension would still be affected by a prior event. Only in the case of liquidation we drop the first restriction, as liquidations directly follow a redemption suspension. Second, for the period following the suspension event, we only include those daily observations on which the trading remains suspended. For example, if a fund resumes the issue and redemption process after a temporary trading suspension of two weeks, the observations of the remaining third week will be omitted.

Fig. 3 illustrates the secondary market activities shortly before and after the trading suspension event. Panel a depicts how the development of the daily pricespread around the suspension event differs across suspension types. Generally, the price-spread is negative but relatively small when the issue of additional shares is suspended, and negative but large when the redemption of shares is suspended or when the fund is being liquidated. In detail, in the event that the fund suspends 
the issue of additional shares, the price-spread is negative prior to the suspension. With the beginning of the issue suspension, the price-spread level dips slightly. In the contrary event that the fund suspends the redemption of shares, the pricespread prior to the suspension remains close to zero, then instantaneously shifts to a larger level on the day of the suspension, and finally remains at the new level during the suspension period. In the event that the fund already has suspended the redemption of shares and then announces the liquidation of the fund, the price-spread prior to the liquidation announcement is already at a high positive level. After the liquidation, the price-spread remains on the same high positive level without any obvious changes. Panel $b$ shows that the daily secondary market trading volumes increase from the day the fund suspends the redemption or both the issue and redemption. In contrast, there is no clear change in the daily trading volume when the fund management suspends the issue of additional shares. In the case that a fund that has already suspended the redemption of shares then announces its liquidation, there is a temporary higher trading volume after the liquidation announcement. A potential explanation for the temporary increase in the trading volume might be that from the official announcement it becomes certain that fund shares will not be redeemable in the future and that the fund's real estate properties will be sold potentially below fair value. Several shareholders might react to this new information by selling their shares on the secondary market.

Besides the major variables of interest, we include the following fund specific control variables in our analysis. First, we include daily 12-month rolling total net fund returns as a control variable. Lower fund returns will increase investors' willingness to redeem their shares to the fund management company or to sell them on the secondary market. On the one hand, a higher supply of OREF shares on the secondary market will result in a higher price-spread. On the other hand, higher redemption requests increase the risk that the fund management company will suspend the redemption of shares. The same rationale applies to higher fund returns, i.e., higher returns will lead to a lower secondary market trading activity and a higher secondary market price while at the same time higher requests for the additional issue of fund shares might lead to an issue suspension. Second, we include front-end loads as a control variable. We calculate front-end loads in accordance with Fecht and Wedow (2014) as the relative difference between the daily offered share price and the net asset value per share. Front-end loads are charged by fund management companies to cover distribution and administration costs. On the contrary, when an investor buys fund shares on the secondary market, no front-end load is charged. Instead, the investor faces direct costs, i.e., banking and brokerage fees, as well as indirect costs in terms of bid-ask spread. The mutual fund literature documents that front-end loads greatly impact the direct trading between investors and the fund management company (Barber et al. 2005; Huang et al. 2007; Gil-Bazo and RuizVerdú 2009). Fecht and Wedow (2014) find that OREFs with higher front-end loads exhibit lower capital outflows, in particularly during the 2005-2006 crisis. This indicates that front-end loads represent a hurdle for investors to (prematurely) ask for the redemption of their shares and therefore front-end loads have a mitigating effect on capital outflows in crisis situations. The influence of front-end loads on secondary market trading activities for fund shares is not well documented. We expect a nega- 
Table 3 Summary statistics of key regression variables

\begin{tabular}{lllllll}
\hline & Mean & $\begin{array}{l}\text { Standard } \\
\text { Deviation }\end{array}$ & Median & Minimum & Maximum & Observations \\
\hline Trading Volume & 0.012 & 0.027 & 0.003 & 0.000 & 0.838 & 53,263 \\
Price-Spread & 7.988 & 13.817 & 0.034 & -10.616 & 61.235 & 54,754 \\
Age & 17.404 & 12.819 & 13.022 & 0.000 & 51.334 & 54,898 \\
Front-Load & 5.149 & 0.448 & 5.011 & 2.991 & 8.519 & 46,718 \\
Return & 1.076 & 6.171 & 2.531 & -39.339 & 24.152 & 53,583 \\
$\quad$ not in liquidation & 3.148 & 2.939 & 2.921 & -23.992 & 21.672 & 41,574 \\
Size & 4.179 & 3.548 & 3.156 & 0.012 & 14.712 & 53,817 \\
\hline
\end{tabular}

This table reports the summary statistics for the key regression variables. Trading Volume (\%) is the numbers of shares traded on the secondary market relative to the total shares outstanding. Price-Spread (\%) is the difference between net asset value per share and secondary market price per share divided by the net asset value per share. Age is calculated as the number of years since fund inception day. Front-Load (\%) is the relative difference between issue price and net asset value per share. Return (\%) is the yearly rolling total net return. Size is the assets under management, listed in billions. All variables are observed on a daily basis, except Size. Size is observed monthly and then linearly interpolated to a daily frequency

tive relationship between front-load fees and the price-spread. With higher front-end loads, more investors will try to buy OREF shares on the secondary market, which leads to a higher secondary market price and therefore a lower price-spread. Finally, we included fund size measured by the total assets under management in billions and fund age in years as control variables. We expect that size and age affect the risk of trading suspensions as well as the secondary market trading volumes. In fact, Fecht and Wedow (2014) find that during the first crisis in December 2005 to June 2006, larger and older funds experienced lower outflows.

Table 3 reports the mean, standard deviation, median, minimum, and maximum for the key regression variables. The daily trading volume, i.e., the number of traded shares per day relative to the total shares outstanding is on average $0.01 \%$ and can peak to $0.84 \%$. The secondary market price of OREFs on average is $7.99 \%$ below the net asset value per share. The secondary market price can deviate significantly from the net asset value per share as indicated by the minimum and maximum values of $-10.62 \%$ and $61.24 \%$. The fund age in our sample varies between 0.00 and 51.33 years, meaning that at least one fund was launched during the observation period and the age of the oldest fund was 51.33 years at the end of the sample period in October 2017. The front-end load of OREFs is on average 5.15\%. Maurer et al. (2004, p. 7) point out that the relatively high front-end load of German OREFs "build an effective barrier which make short-term investment horizons, and therefore, frequent transaction with the fund units, unattractive." The average return per annum in our sample is $1.08 \%$ which is lower compared to Maurer et al. (2004), Fecht and Wedow (2014), and Downs et al. (2016) who report average returns of 6.06\%, 3.92\%, and $4.73 \%$ respectively. The low average return in our sample can be attributed to a general decrease in the returns of OREFs after 2009 and to the portfolio revaluations of distressed OREFs. Fig. 4 illustrates these two negative influences on OREF returns. Excluding the daily returns of the funds during the liquidation phase, the average return of German OREFs is 3.15\%. The average OREF size is $€ 4.18 \mathrm{bn}$. The largest fund manages $€ 14.71 \mathrm{bn}$ while the smallest fund manages $€ 12 \mathrm{~m}$. 


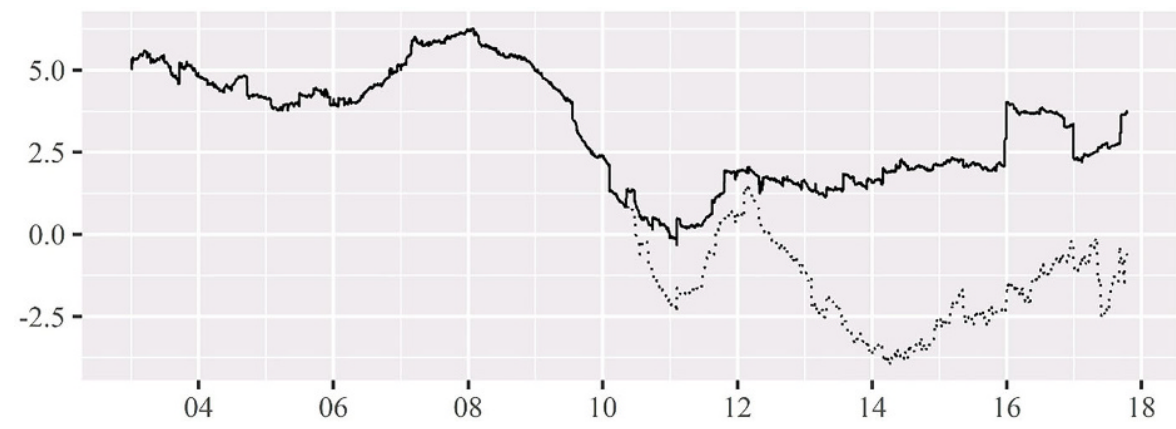

Fig. 4 Rolling returns of German open-end real estate funds (This figure shows the daily rolling total net return $(\%)$ per annum of German open-end real estate funds. The dotted line represents the daily returns averaged across all funds while the solid line excludes the funds in liquidation)

Table 4 reports correlation coefficients for all variables. The corresponding $p$ values are reported in parentheses.

The majority of the pairwise correlation coefficients are weak. However, there are strong positive relations between liquidation and price-spread $(\rho=0.80)$ and between age and size $(\rho=0.60)$. Also, there are strong negative relations between return and price-spread $(\rho=-0.67)$ and return and liquidation $(\rho=-0.62)$. The strong negative correlation between return and liquidation can be explained as OREFs in liquidation potentially must devaluate their assets and may sell their properties below fair value (see Sect. 2.1.2) resulting in a negative return. Lastly a negative moderate correlation can be observed between liquidation and size $(\rho=-0.42)$ which might be due to the fact that OREFs in liquidation gradually sell their real estate properties and payout the revenues to the shareholders resulting in a decrease in size.

\subsection{Methodology}

We use a piecewise linear regression model to analyze the secondary market activities for open-end real estate funds in Germany. Our aim is to investigate the effects on secondary market prices and trading volumes when the issue/redemption process is restricted. To estimate the effect of the temporary issue and redemption suspensions as well as permanent fund liquidations on the trading volume and pricespread, we use four dummy variables. The daily Issue dummy variable equals one if the fund has suspended the issue of new shares and zero otherwise. The daily $R e-$ demption dummy variable equals one if the fund has suspended the redemption of shares and zero otherwise. The daily Both dummy variable equals one if the fund has suspended both the issue and redemption of shares. Lastly, the Liquidation dummy variable equals one from the day the fund management has announced the liquidation of the fund and therefore stopped the issue and redemption of shares. All four dummy variables are mutually exclusive. The daily Trading Volume is calculated as the ratio of the traded number of shares relative to the total shares outstanding, 


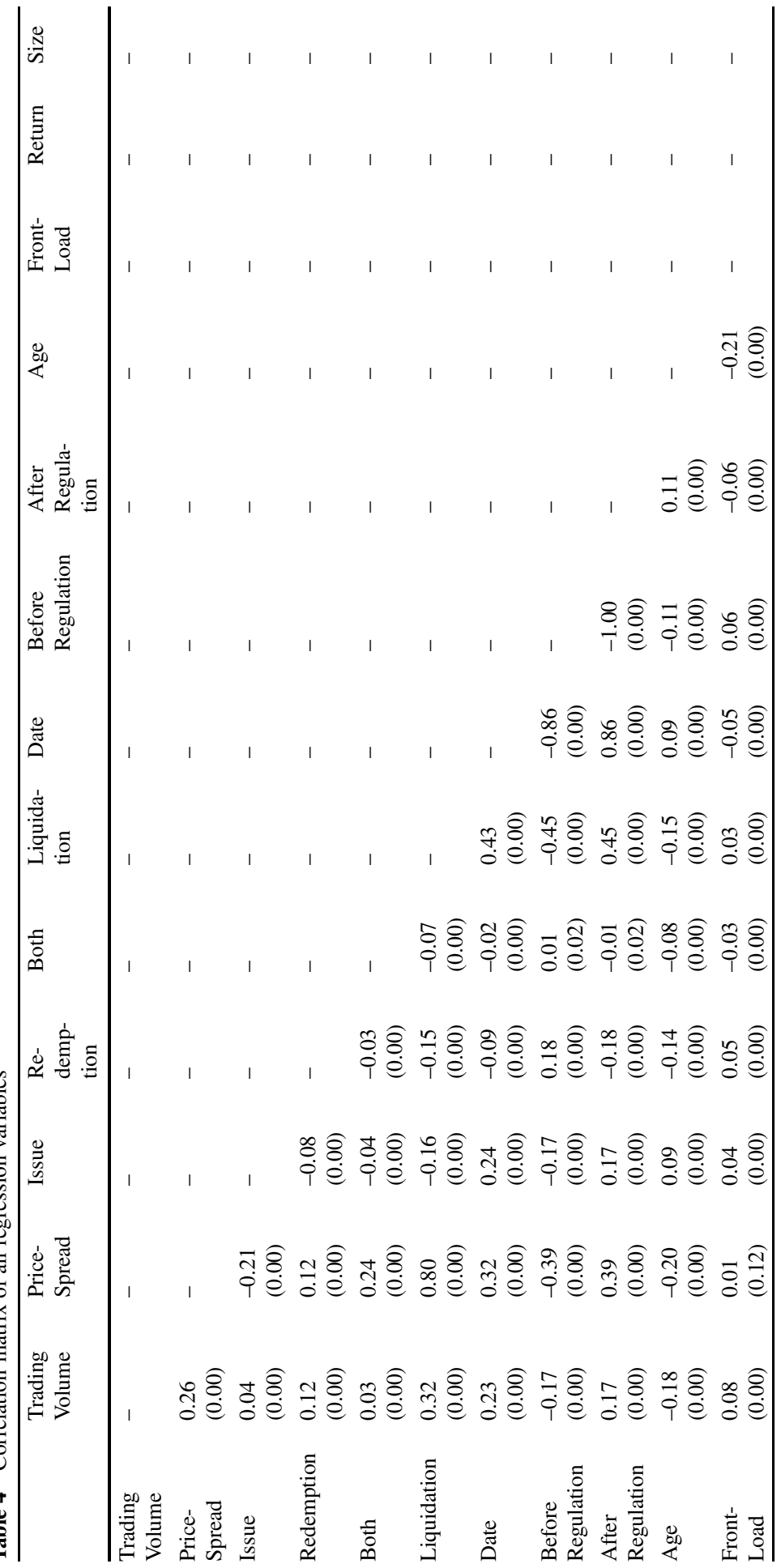




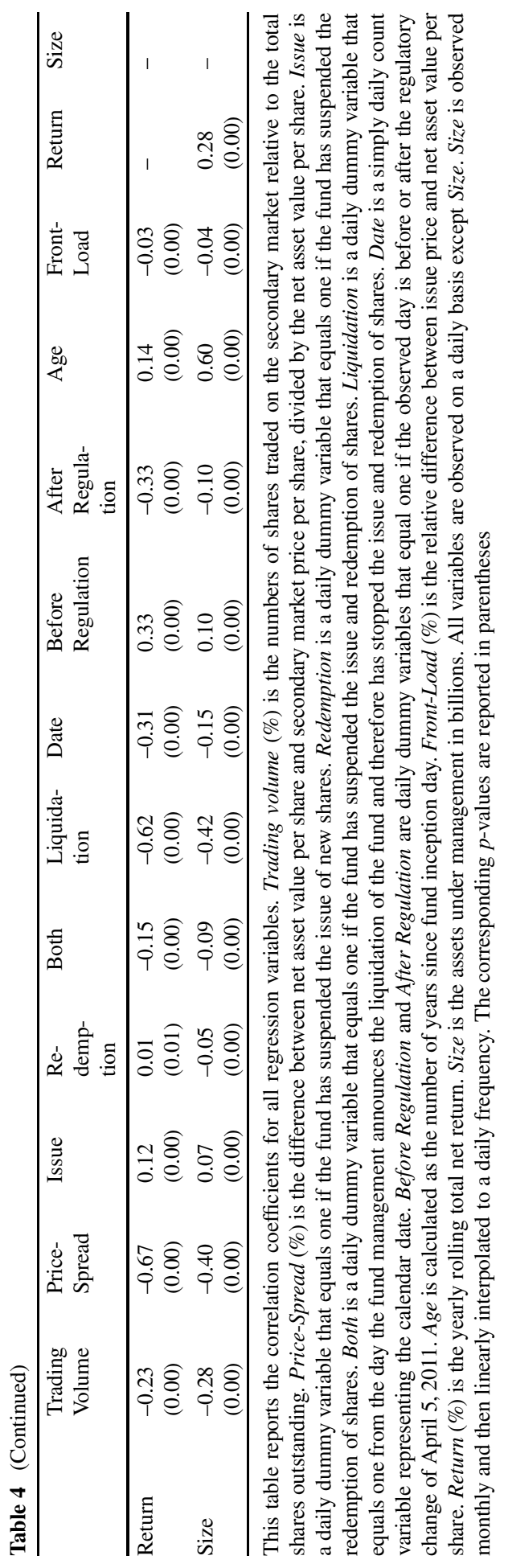


then multiplied by 100 . First, we estimate the linear model without a breakpoint by ordinary least-squares regression:

$$
\begin{aligned}
\text { Trading } \text { Volume }_{i, t} & =\alpha \\
& +\beta_{1} \text { Date } \\
& +\beta_{2} \text { Issue }_{i, t} \\
& +\beta_{3} \text { Redemption }_{i, t} \\
& +\beta_{4} \text { Both }_{i, t} \\
& +\beta_{5} \text { Liquidation }_{i, t} \\
& +\beta_{6} \text { Age }_{i, t} \\
& +\beta_{7} \text { Front }_{- \text {Load }_{i, t}} \\
& +\beta_{8} \text { Return }_{i, t} \\
& +\beta_{9} \text { Size }_{i, t}+\varepsilon_{i, t} .
\end{aligned}
$$

Then we modify the basic linear model into a piecewise regression model with two segments to estimate the effects of the regulatory changes on the trading volume:

$$
\begin{aligned}
\text { Trading }_{\text {Volume }}, t & =a_{1} I(\text { Date }<\text { regulatory Break }) \\
& \left.+\alpha_{2} \text { I(Date } \geq \text { regulatory Break }\right) \\
& +\beta_{1} \text { Date } I(\text { Date }<\text { regulatory Break }) \\
& +\beta_{2} \text { Date } I(\text { Date } \geq \text { regulatory Break }) \\
& +\beta_{3} \text { Issue }_{i, t} \\
& +\beta_{4} \text { Redemption }_{i, t} \\
& +\beta_{5} \text { Both }_{i, t} \\
& +\beta_{6} \text { Liquidation }_{i, t} \\
& +\beta_{7} \text { Age }_{i, t} \\
& +\beta_{8}{\text { Front }- \text { Load }_{i, t}} \\
& +\beta_{9} \text { Return }_{i, t} \\
& +\beta_{10} \text { Size }_{i, t}+\varepsilon_{i, t} .
\end{aligned}
$$

We set the breakpoint between the two segments to the regulatory break of April 5, 2011, which marks the introduction of the minimum holding and notice periods. In a later robustness analysis, the optimal breakpoint will be estimated from the historical data.

We use the same linear model to estimate the effects of the temporary issue and redemption suspensions as well as permanent fund liquidations on the spread between the net asset value per share and the secondary market price. The PriceSpread is calculated according to Lee et al. (1991), Barkham and Ward (1999), and 
Schnejdar et al. (2019) as the difference between the net asset value per share and the secondary market price, divided by the net asset value per share.

$$
\begin{aligned}
\text { Price-Spread }_{i, t} & =\alpha \\
& +\beta_{1} \text { Date } \\
& +\beta_{2} \text { Issue }_{i, t} \\
& +\beta_{3} \text { Redemption }_{i, t} \\
& +\beta_{4} \text { Both }_{i, t} \\
& +\beta_{5} \text { Liquidation }_{i, t} \\
& +\beta_{6} \text { Age }_{i, t} \\
& +\beta_{7} \text { Front }_{- \text {Load }_{i, t}} \\
& +\beta_{8} \text { Return }_{i, t} \\
& +\beta_{9} \text { Size }_{i, t}+\varepsilon_{i, t} .
\end{aligned}
$$

Again, we extend the basic linear model to a piecewise regression model with the breakpoint set to April 5, 2011, to estimate the effects of the regulatory changes on the price-spread:

$$
\begin{aligned}
\text { Price-Spread }_{i, t} & =a_{1} I(\text { Date }<\text { regulatory Break }) \\
& +\alpha_{2} I(\text { Date } \geq \text { regulatory Break }) \\
& +\beta_{1} \text { Date } I(\text { Date }<\text { regulatory Break }) \\
& +\beta_{2} \text { Date } I(\text { Date } \geq \text { regulatory Break }) \\
& +\beta_{3} \text { Issue }_{i, t} \\
& +\beta_{4} \text { Redemption }_{i, t} \\
& +\beta_{5} \text { Both }_{i, t} \\
& +\beta_{6} \text { Liquidation }_{i, t} \\
& +\beta_{7} \text { Age }_{i, t} \\
& +\beta_{8}{\text { Front }- \text { Load }_{i, t}} \\
& +\beta_{9} \text { Return }_{i, t} \\
& +\beta_{10} \text { Size }_{i, t}+\varepsilon_{i, t} .
\end{aligned}
$$

Finally, we use a Wald F-test to compare each of the linear models with the corresponding piecewise linear models. Formally, we test for the null hypothesis that the coefficients of the simple linear model equal the coefficients of the piecewise linear model. If the resulting F-statistic results in a rejection of the null hypothesis, we can conclude that the intercept and the trend differ for the period before and after the introduction of the minimum holding period together with the notice period.

\section{Results}

\subsection{Trading Volume}

Table 5 summarizes the ordinary least-squares results for model (1) and model (2). We estimate both models separately for each dummy variable and for the full specifications, including all dummy variables in the respective model. This allows us to 


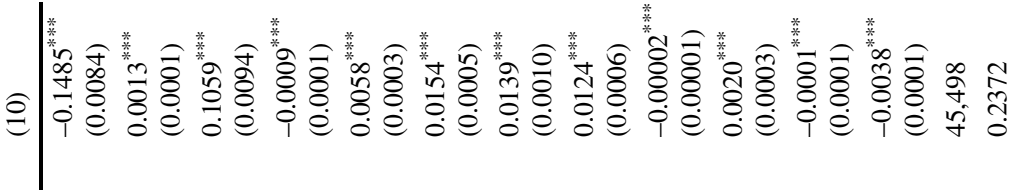

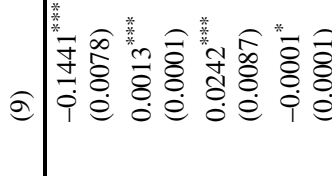

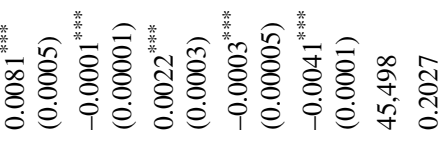

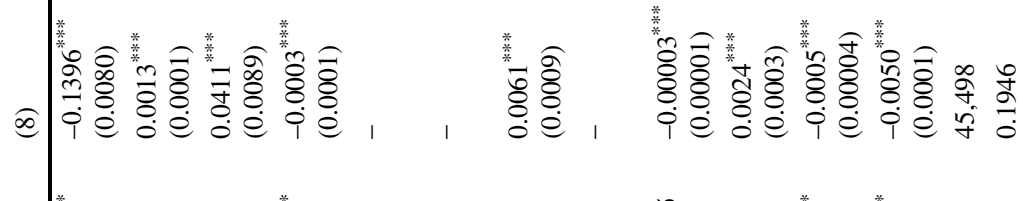

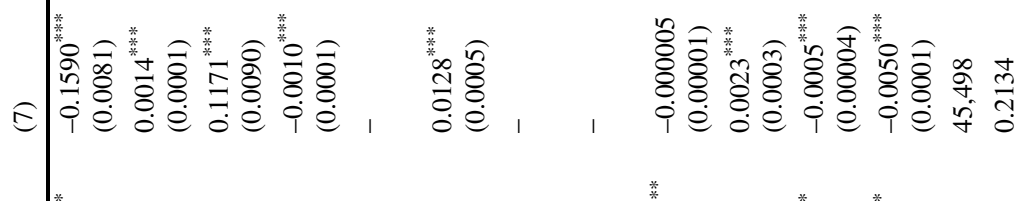

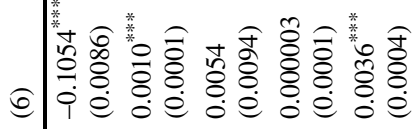

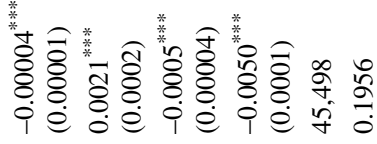

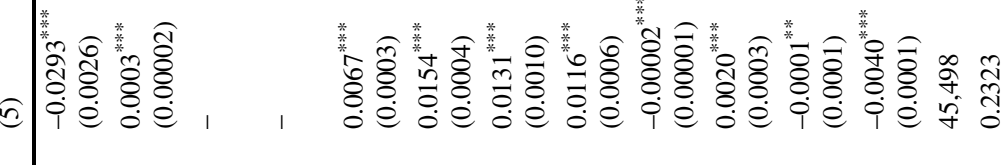

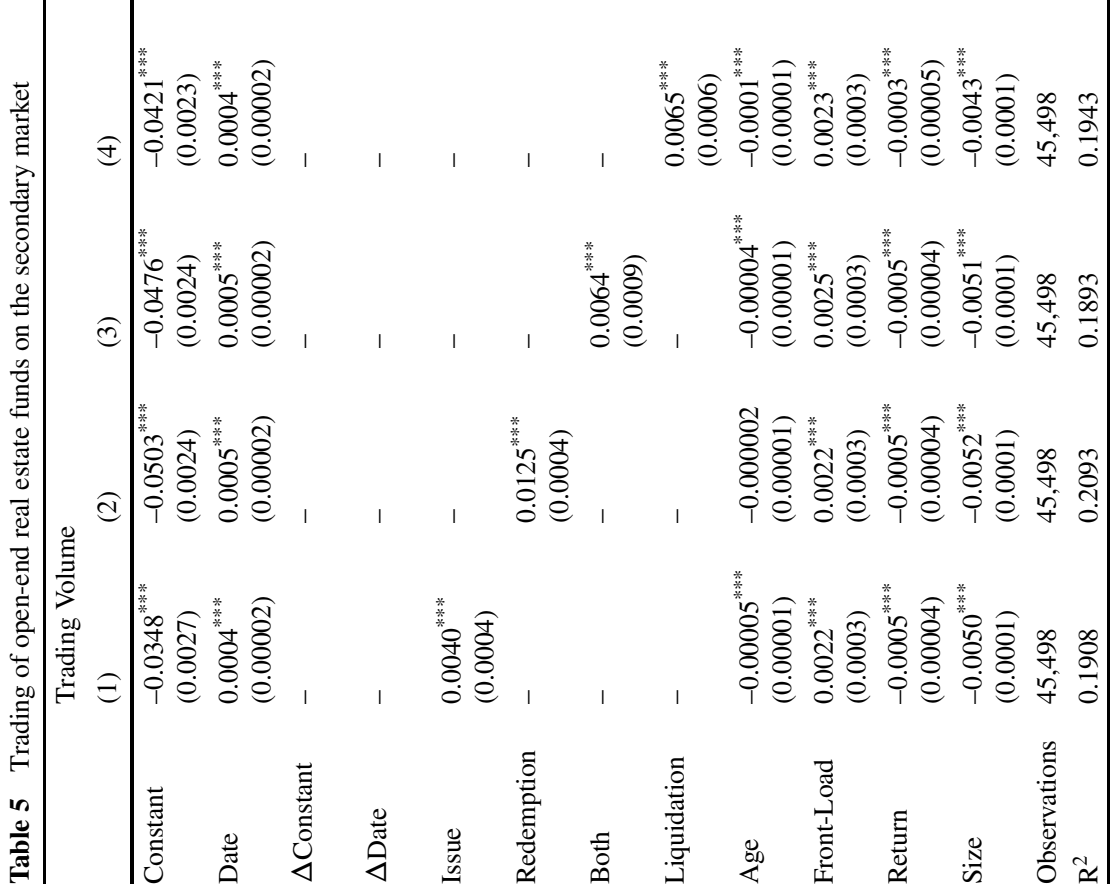




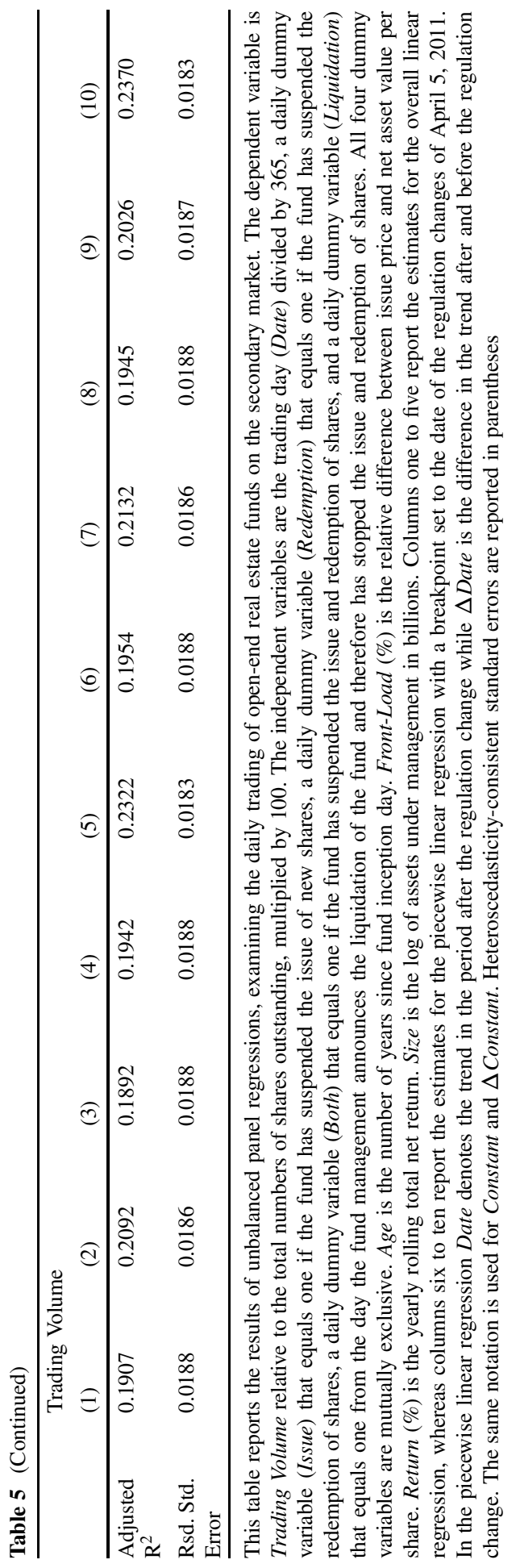


see the individual effects of the temporary trading suspensions and the liquidation on the secondary market trading volume. Columns one to five report the results for the simple linear model, and columns six to ten show the piecewise linear model estimates. Heteroscedasticity-consistent standard errors are reported in parentheses.

According to hypothesis 1, the expected sign of Issue should be positive, i.e., in situations when the fund management suspends the issue of additional shares, there tends to be higher trading activity on secondary markets. The estimates are significant and positive for all model specifications. In the fully specified models, the issue dummy estimate is significant and positive with a value of 0.0067 for the simple linear model, and also significant and positive with a value of 0.0058 for the piecewise linear model. Based on these regression results, hypothesis 1 can be confirmed.

According to hypothesis 3, the expected sign of Redemption should be positive, i.e., in situations when the fund management suspends the redemption of shares, there will be higher trading activity on secondary markets. The estimates are positive and significant for all models, confirming hypothesis 3 . In detail, the estimate is 0.0154 for the fully specified linear model and also 0.0154 for the fully specified piecewise linear model.

According to hypothesis 5, the expected sign of Liquidation should be positive, i.e., the secondary market trading is higher when a fund is being liquidated. Again, the model estimates are positive and significant for all model specifications, confirming hypothesis 5 . The estimate is 0.0116 for the fully specified linear model and 0.0124 for the fully specified piecewise linear model.

According to hypothesis 7 , in the piecewise linear model the expected sign of Date should be positive and $\Delta$ Date should be negative, i.e., the secondary market trading of open-end real estate funds is increasing at a higher rate since the introduction of the notice period. The piecewise linear regression model has two segments: the first segment covers the period before the introduction of the minimum holding and notice periods, and the second segment covers the period after the introduction. In columns 6-10, the Date coefficient is the trend in the segment covering the period after the introduction of the notice period, while the $\Delta$ Date coefficient is the difference between the trend components in the segment after and before the introduction of the notice period. The estimates for Date are positive and significant for all model specifications. The $\Delta$ Date estimates are negative and significant for models 7-10, but positive and not significant for model 6 . For the fully specified model, the trend coefficient for the second segment of the piecewise regression is 0.0013 , implying that trading of OREF shares on the secondary market increases in the period after the introduction of the notice period. Before the introduction of the notice period, secondary market trading also increases in the course of time but with a lower trend of $0.0004=0.0013-0.0009$. Combining the information on the estimates for Date and $\Delta$ Date confirms hypothesis 7.

The model estimates for the fund specific control variables are significant for the fully specified models and with two exceptions also for partially specified models. For the fully specified piecewise linear model, the estimate for Age is -0.00002 and for Size -0.0038 . Therefore, shares of older and larger funds are traded less on secondary markets. The Return estimate is -0.0001 in the fully specified piecewise 
Table 6 Testing for a structural break in the trading volume of OREFs on the secondary market

\begin{tabular}{llll}
\hline Res.Df & Df & F & $\operatorname{Pr}(>\mathrm{F})$ \\
\hline 45,488 & - & - & - \\
45,486 & 2 & 125.85 & $<2.2 \mathrm{e}-16^{* * *}$ \\
\hline
\end{tabular}

This table reports the summary statistics resulting from a Wald F-test that examines if the trading of openend real estate funds exhibits a structural break after the regulation change of April 5, 2011. The test compares the overall linear model (1) with the piecewise linear model (2), whereby a heteroscedasticityconsistent covariance matrix is used. The first column shows residual degrees of freedom (Res.DF), the second column reports the degrees of freedom difference between the two models $(D f)$, the third column reports the F-test statistic $(F)$, and the last column reports the corresponding $p$-value $(\operatorname{Pr}(>F))$

linear model, implying a negative marginal effect of past performance on secondary market trading. A potential reason might be that shareholders are less willing to sell their shares when the fund performs well. The estimate for Front-Load is 0.0020 for the fully specified model indicating a positive effect of the front-load fee on secondary market trading. The front-load estimates might suggest that with a higher front-end load, investors tend to buy new shares on the secondary market rather than directly from the fund management company.

Table 6 reports the Wald test statistics for a comparison of models (1) and (2). The resulting F-statistic of 125.85 indicates that the null hypothesis, which states that the estimates of both models are equivalent, is rejected. The Wald test supports the previous conclusion of the existence of a structural break in the time-series of secondary market trades. Because the estimated trend after the introduction of the notice period is higher than before, we find additional statistical support to confirm hypothesis 7 .

\subsection{Price-Spread}

Table 7 summarizes the ordinary least-squares results for model (3) and model (4). Again, we estimate the two models for each dummy variable separately and fully specified, with all dummy variables estimated in one model. Columns one to five report the results for the simple linear model, and columns six to ten show the piecewise linear model estimates. Heteroscedasticity-consistent standard errors are reported in parentheses.

According to hypothesis 2, the expected sign of Issue should be negative, i.e., the secondary market price is above the net asset value per share when the issue of shares is suspended. The model estimates are significant and negative for all model specifications. In the fully specified models, the issue dummy estimate is -1.725 for the simple linear model and -0.412 for the piecewise linear model. Therefore, hypothesis 2 can be confirmed.

According to hypothesis 4, we expect the sign of Redemption to be positive, i.e., the secondary market price is below the net asset value per share when the redemption of shares to the fund management company is suspended. The model estimates are positive and significant for all models, confirming hypothesis 4 . In detail, the estimate is 13.670 for the fully specified linear model and 13.414 for the fully specified piecewise linear model. 


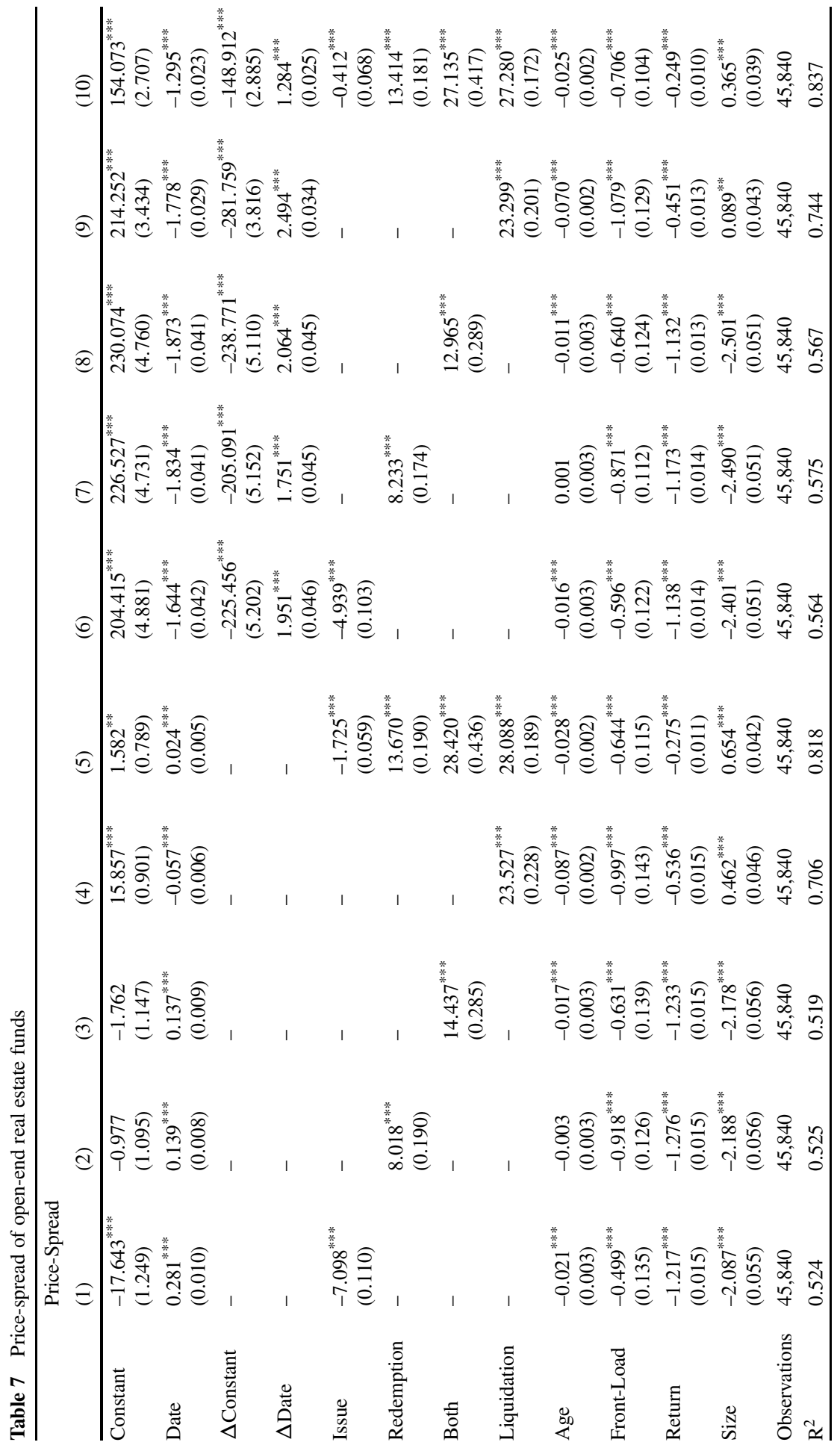




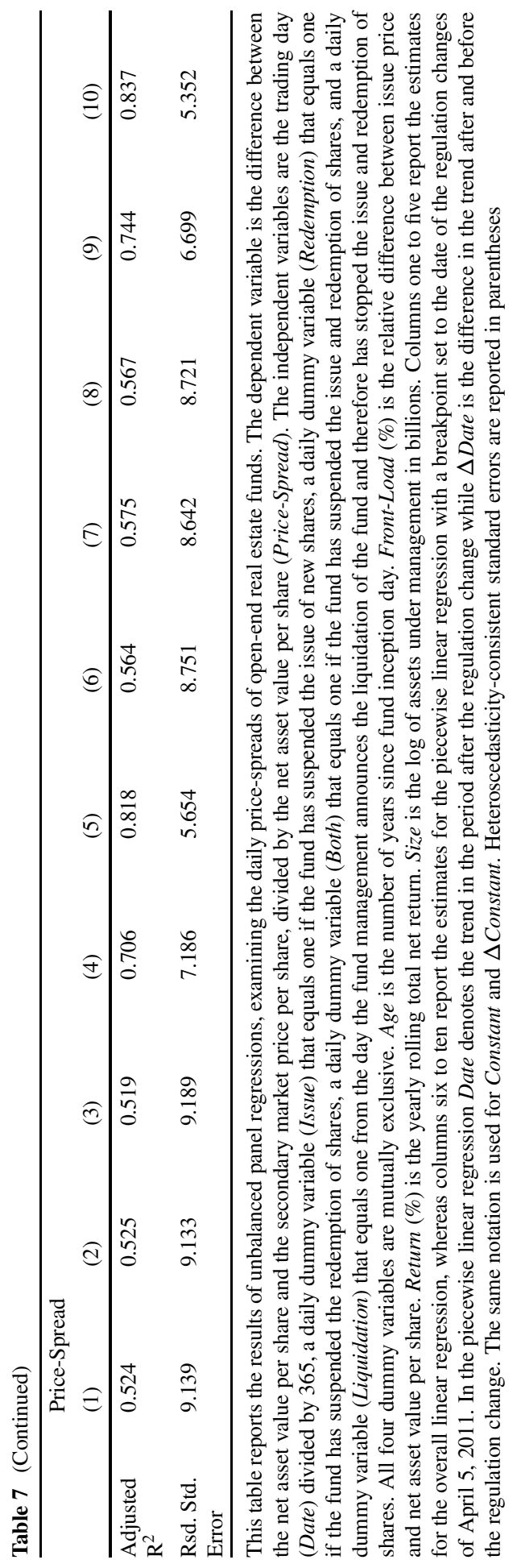


Table 8 Testing for a structural break in the price-spread of OREFs on the secondary market

\begin{tabular}{llll}
\hline Res.Df & Df & F & $\operatorname{Pr}(>\mathrm{F})$ \\
\hline 45,830 & - & - & - \\
45,828 & 2 & 1774.2 & $<2.2 \mathrm{e}-16 * * *$ \\
\hline
\end{tabular}

This table reports the summary statistics resulting from a Wald F-test that examines if the price-spread of open-end real estate funds exhibits a structural break after the regulation change of April 5, 2011. The test compares the overall linear model (3) with the piecewise linear model (4), whereby a heteroscedasticityconsistent covariance matrix is used. The first column shows residual degrees of freedom (Res.DF), the second column reports the degrees of freedom difference between the two models $(D f)$, the third column reports the F-test statistic $(F)$, and the last column reports the corresponding $p$-value $(\operatorname{Pr}(>F))$

According to hypothesis 6, i.e., the secondary market price is below the net asset value per share when the fund is being liquidated, the sign of Liquidation should be positive. The model estimates are positive and significant for all models, confirming hypothesis 6 . In detail, the estimate is 28.088 for the fully specified linear model and 27.280 for the fully specified piecewise linear model.

According to hypothesis 8 , in the piecewise linear model the expected sign of Date should be positive and $\Delta$ Date should be negative, i.e., the spread between the net asset value per share and the secondary market price increases after the introduction of the notice period. The estimated coefficients are all significant. The estimated Date coefficients are negative and the estimated $\Delta$ Date coefficients are positive for all piecewise linear model specifications. For the fully specified model, the estimated trend in the price-spread is $-0.0011=-1.295+1.284$ for the period before the introduction of the notice period and -1.295 after introduction of the notice period. Therefore, hypothesis 8 cannot be confirmed.

The estimates for the fund specific control variables are all significant in the fully specified models. In the piecewise linear model, the estimate for Age is -0.025 and for Size 0.365. Interestingly, the estimate for Front-Load is negative with a value of -0.706 . This indicates that the secondary market price relative to the net asset value per share tends to be higher for funds with higher front-end load fees. Lastly, the estimate for Return is -0.249 , implying that the secondary market price relative to the net asset value per share tends to be positive related to the preceding annual return.

Table 8 reports the Wald test statistics for model (3) and model (4). The resulting F-statistic of 1774.2 indicates the null hypothesis that the estimated coefficients of the simple linear model and the piecewise linear model are equivalent is rejected. This supports the conclusion that the introduction of the minimum holding and notice periods has a significant impact on the price-spread even though the impact is not in line with hypothesis 8 . 


\section{Robustness Analysis}

\subsection{Excluding Deka and WestInvest Funds}

The fund management companies Deka and WestInvest do not officially suspend the issue of additional shares. Instead, they define contingents of shares that they will issue over the course of the following year. If the contingent of shares is sold, no additional capital is accepted. Fig. 2 shows that in the years 2016-2017 the secondary market price for Deka and WestInvest funds is above the net asset value per share. This negative price-spread indicates that the fund management in these years issued no additional shares and investors had to buy shares on the secondary market. However, due to the lack of official notifications that the fund management suspended the issue of additional shares, the estimated coefficients, in particular the issue dummy of models (3) and (4), may be biased.

Table 9 summarizes the results of the ordinary least-squares regression for model (3) and model (4). Each column reports the model estimates and the corresponding heteroscedasticity-consistent standard errors in parentheses.

Comparing Table 7 and Table 9 shows that the effects of the temporary issue suspensions are more pronounced when we exclude the funds that use contingents to control liquidity. In particular, the issue estimate for the fully specified piecewise linear model is significant, with a value of -1.288 . Therefore, hypothesis 2 can be re-confirmed, i.e., the secondary market price is above the net asset value per share when the issue of shares is suspended.

\subsection{Polynomial Regression}

In the previous analyses, we used a piecewise linear regression model to analyze the secondary market activities for open-end real estate funds in Germany. In the model, we regressed the daily trading volume and the price-spread on a count variable representing the trading date, and a set of dummy variables indicating on which days the direct trading between the investor and the fund management company is restricted. However, the piecewise linear model implies a constant growth rate and therefore might lead to positive coefficients for the dummy variables. In particular, if the development of trading volumes over time is concave, a piecewise linear regression will automatically result in a significant break with a higher trend in the latter period. To investigate potential biases resulting from the piecewise linear model specification, we estimate a second order polynomial version of the previous 


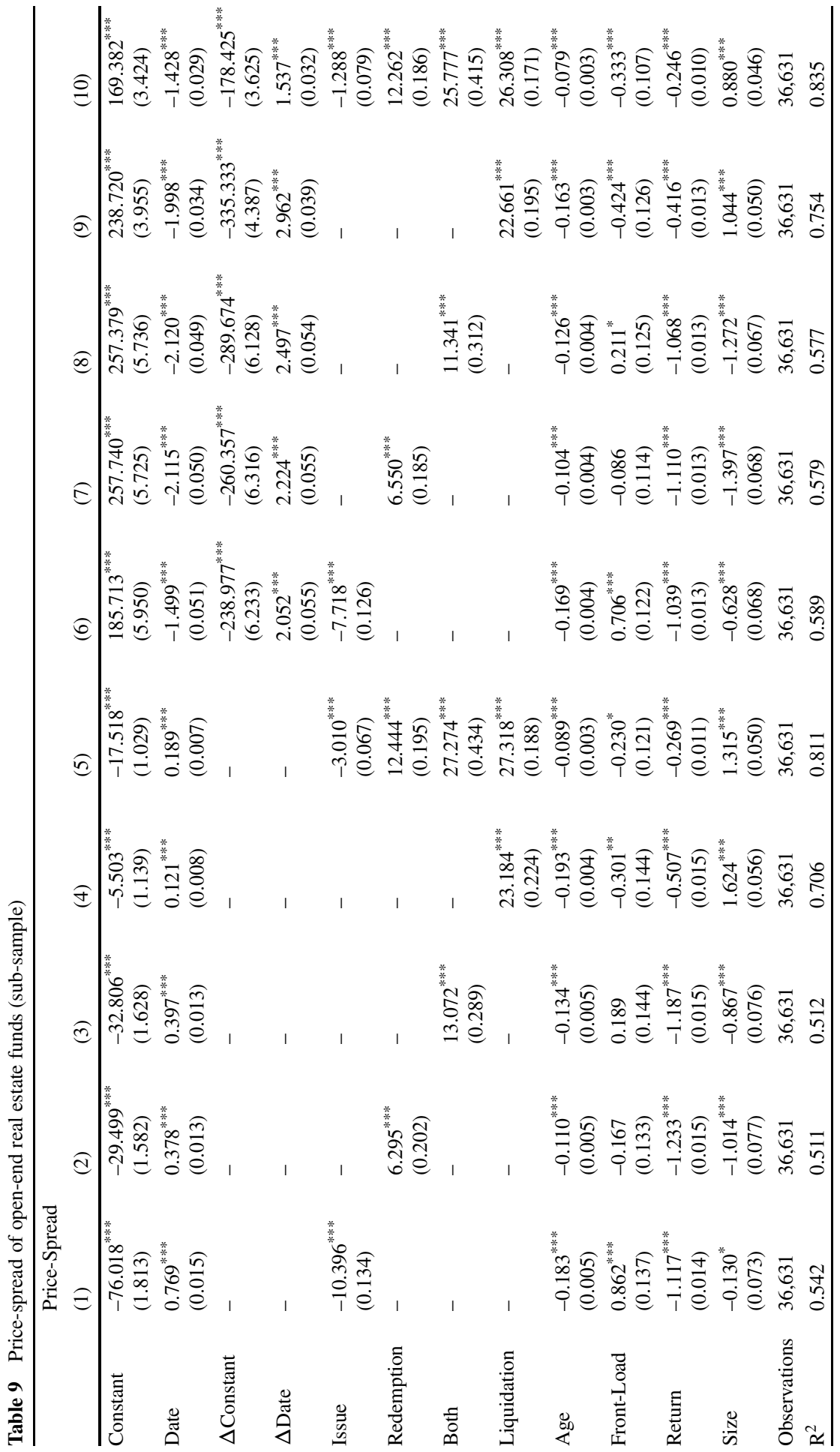




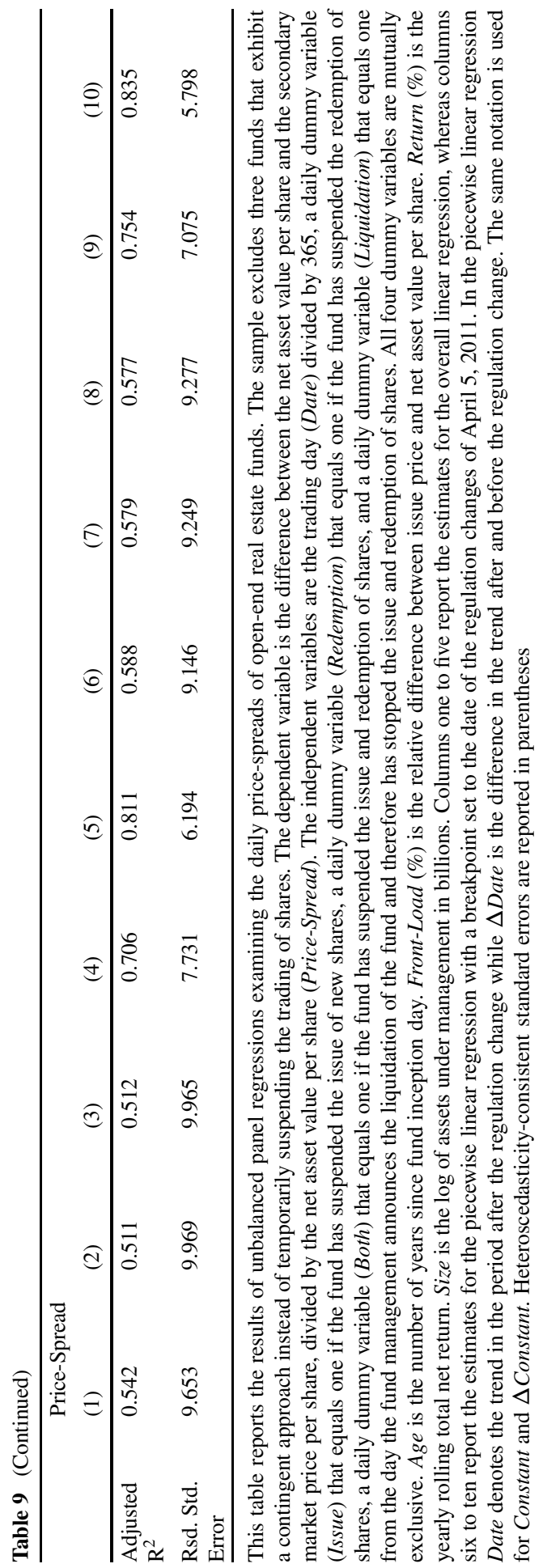


models. The polynomial model specification captures a variety of non-constant trend forms. The polynomial versions of models (1) and (2) are:

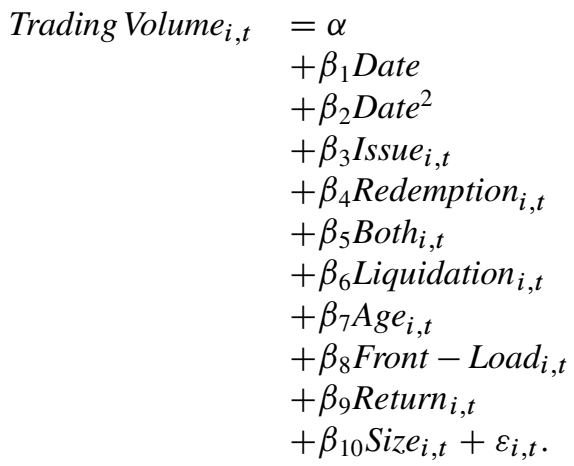

Trading Volume $_{i, t}=a_{1} I($ Date $<$ regulatory Break $)$

$+\alpha_{2} I$ (Date $\geq$ regulatory Break)

$+\beta_{1}$ Date I(Date < regulatory Break $)$

$+\beta_{2}$ Date I(Date $\geq$ regulatory Break $)$

$+\beta_{3}$ Date $^{2}$ I(Date < regulatory Break)

$+\beta_{4}$ Date $^{2}$ I(Date $\geq$ regulatory Break)

$+\beta_{5}$ Issue $_{i, t}$

$+\beta_{6}$ Redemption $_{i, t}$

$+\beta_{7}$ Both $_{i, t}$

$+\beta_{8}$ Liquidation $_{i, t}$

$+\beta_{9}$ Age $_{i, t}$

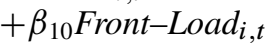

$+\beta_{11}$ Return $_{i, t}$

$+\beta_{12}$ Size $_{i, t}+\varepsilon_{i, t}$.

Table 10 summarizes the results of the ordinary least-squares regression for model (5) and model (6). Columns one to five report the results for the simple polynomial model, while columns six to ten report the results for the segmented polynomial model. Again, each column reports the model estimates and the corresponding heteroscedasticity-consistent standard errors in parentheses.

First, comparing the results of the linear models in Table 5 with the polynomial models in Table 10 shows that the coefficients for the dummy and control variables are almost identical. Therefore, the previous conclusions on the effects of the temporary trading suspensions and liquidation on the secondary market trading volume are not only a result of the linear model specification but still hold in a non-linear model specification. In Table 10, the coefficients of major interest are the variables Date, Date ${ }^{2}, \Delta$ Date, and $\Delta$ Date $^{2}$. The Date coefficient represents the linear while Date $^{2}$ measures the non-linear, quadratic trend component after the regulatory break. 


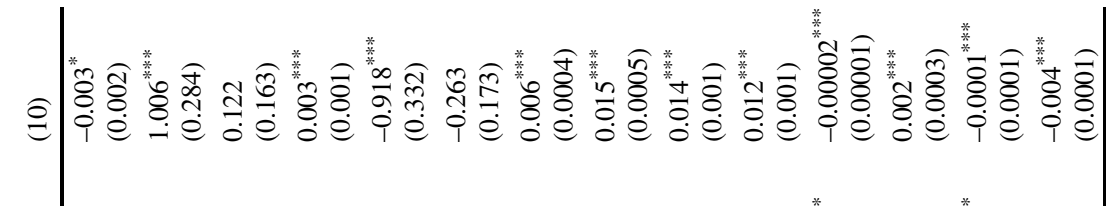

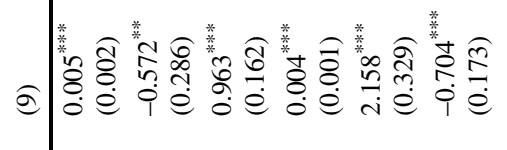

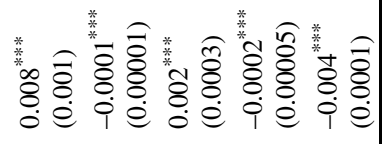

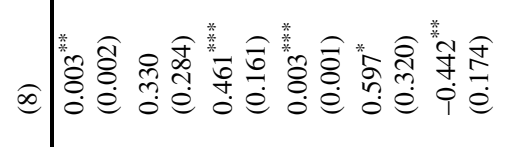

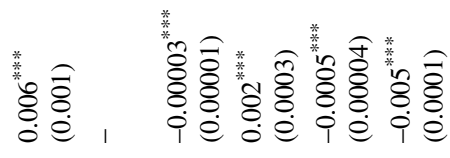

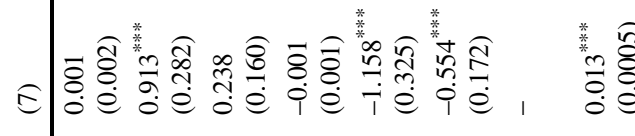

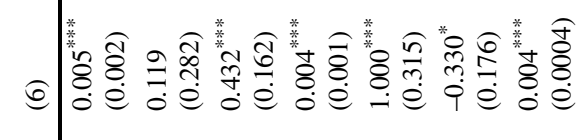

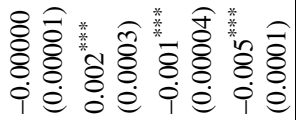

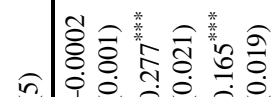

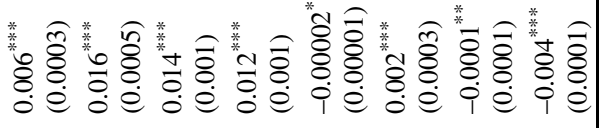

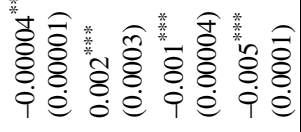

(

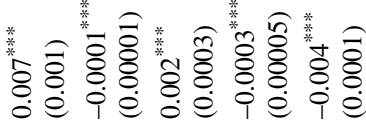

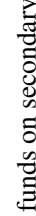

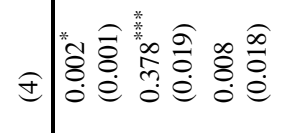

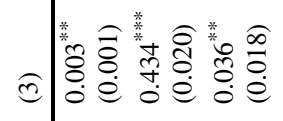

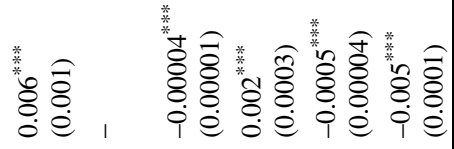

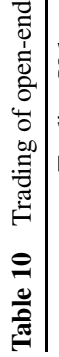

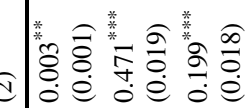

䔔告

粪委

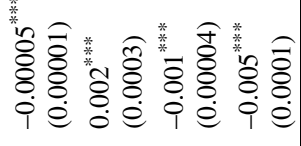

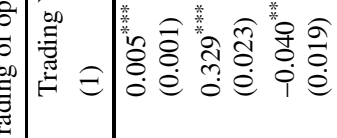

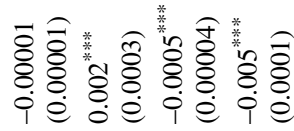

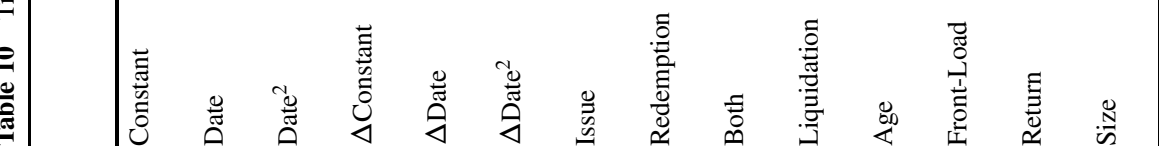




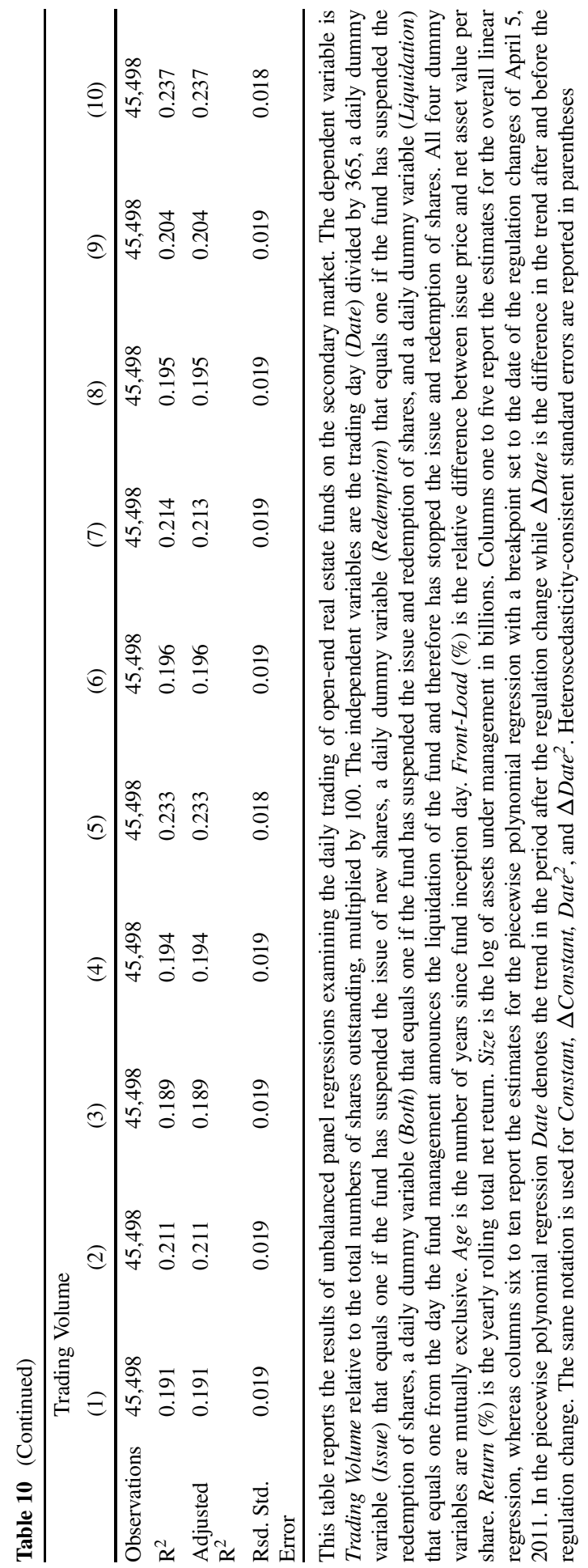


The estimated coefficients for the fully specified segmented polynomial model are reported in column ten. The Date estimate is significant and positive with a value of 1.006 and the $\Delta$ Date is significant and negative with a value of -0.918 . The quadratic trend component estimates are 0.122 for Date $^{2}$ and -0.263 for $\Delta$ Date $^{2}$ but neither estimate is significant. Therefore, in line with the previous findings in Sect. 4.1 , we find a positive linear trend of $0.088=1.006-0.918$ in the period before the regulatory change and also a positive but larger trend of 1.006 in the subsequent period. Combining the information on the estimated trend component coefficients, we can conclude that despite that the segmented polynomial model allows a variety of different forms of trend in the trading volume, our estimates represent a simple segmented linear trend over time. In conclusion, hypothesis 7 can be re-confirmed, i.e. the secondary market trading of open-end real estate funds has been increasing at a faster rate since the introduction of the notice period.

We also specify a polynomial version of model (3) and model (4):

$$
\begin{aligned}
& \text { Price-Spread }_{i, t}=\alpha \\
& +\beta_{1} \text { Date } \\
& +\beta_{2} \text { Date }^{2} \\
& +\beta_{3} \text { Issue }_{i, t} \\
& +\beta_{4} \text { Redemption }_{i, t} \\
& +\beta_{5} \text { Both }_{i, t} \\
& +\beta_{6} \text { Liquidation }_{i, t} \\
& +\beta_{7} A g e_{i, t} \\
& +\beta_{8} \text { Front }_{- \text {Load }_{i, t}} \\
& +\beta_{9} \text { Return }_{i, t} \\
& +\beta_{10} \text { Size }_{i, t}+\varepsilon_{i, t} \text {. } \\
& \text { Price-Spread }_{i, t}=a_{1} I(\text { Date }<\text { regulatory Break }) \\
& +\alpha_{2} I \text { (Date } \geq \text { regulatory Break) } \\
& +\beta_{1} \text { Date I(Date < regulatory Break) } \\
& +\beta_{2} \text { Date I(Date } \geq \text { regulatory Break) } \\
& \left.+\beta_{3} \text { Date }^{2} \text { I (Date < regulatory Break }\right) \\
& +\beta_{4} \text { Date }^{2} \text { I(Date } \geq \text { regulatory Break) } \\
& +\beta_{5} \text { Issue }_{i, t} \\
& +\beta_{6} \text { Redemption }_{i, t} \\
& +\beta_{7} \text { Both }_{i, t} \\
& +\beta_{8} \text { Liquidation }_{i, t} \\
& +\beta_{9} A g e_{i, t} \\
& +\beta_{10} \text { Front-Load }_{i, t} \\
& +\beta_{11} \text { Return }_{i, t} \\
& +\beta_{12} \text { Size }_{i, t}+\varepsilon_{i, t} \text {. }
\end{aligned}
$$

Table 11 summarizes the results of the ordinary least-squares regression for model (7) and model (8). Columns one to five report the results for the simple polynomial model, while columns six to ten report the results for the segmented polynomial model. Each column reports the model estimates and the corresponding heteroscedasticity-consistent standard errors in parentheses. 


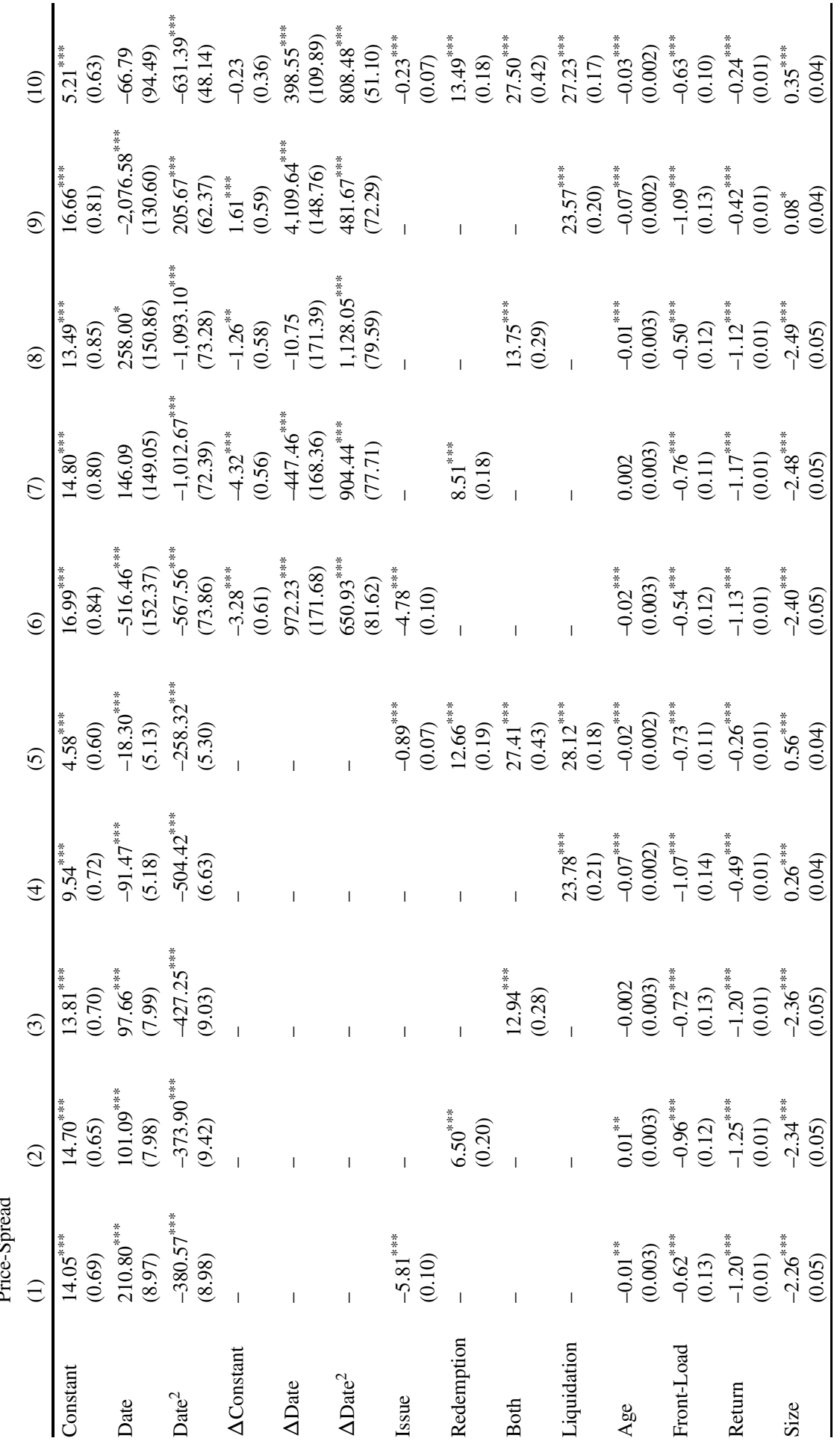




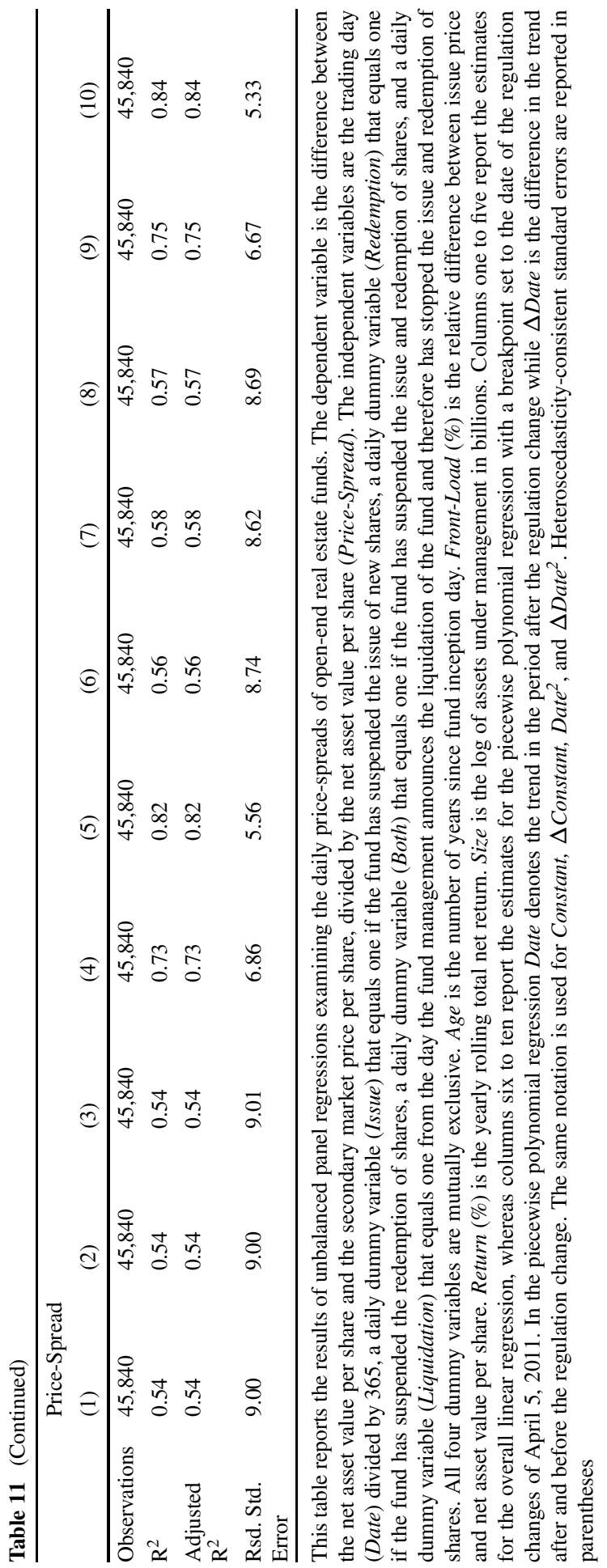




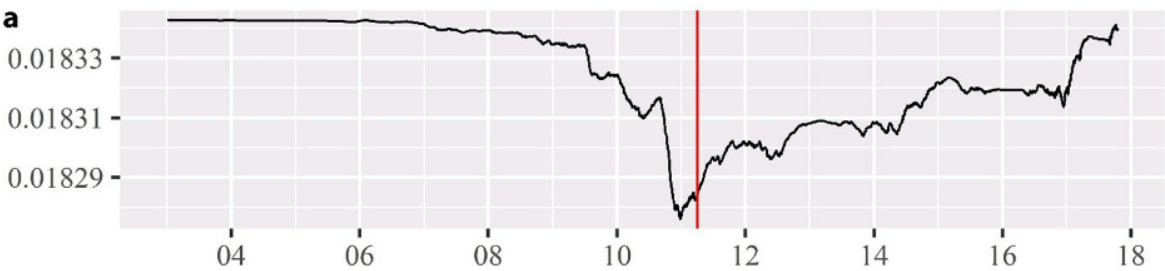

b

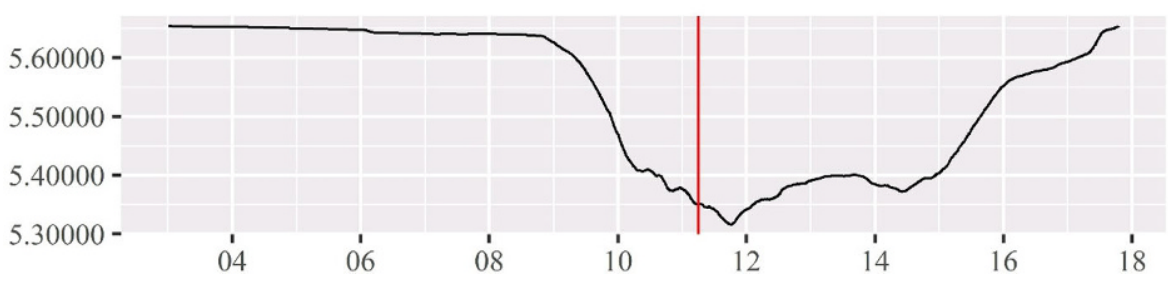

Fig. 5 Estimated break dates for the piecewise linear regression. a Trading Volume. b Price-Spread (This figure shows the residual sum of squares $(R S S)$ estimates for the piecewise linear models with different potential break dates. Panel (a) shows the RSS for estimates of model (2) with the trading volume as the dependent variable. Panel (b) shows the RSS for estimates of model (4) with the price-spread as the dependent variable. The models are estimated for different daily breaks ranging from January 6, 2003, to October 18, 2017. The vertical line shows the official date of the regulatory changes of April 5, 2011)

Comparing the results for the linear models in Table 7 with those of the polynomial models in Table 11 again shows no major differences in the estimates for the control and dummy variable estimates. The variables of interest in Table 11 are Date, Date ${ }^{2}, \Delta$ Date, and $\Delta D_{a t e^{2}}$. In the fully specified segmented polynomial model, the estimated coefficients are -66.79 but not significant for Date, -631.39 for Date $^{2}, 398.55$ for $\Delta$ Date, and 808.48 for $\Delta$ Date $^{2}$. Combining these estimates implies a positive, convex trend in the years before the introduction of the notice period followed by a negative, concave trend after its introduction. Therefore, again, hypothesis 8 cannot be confirmed, i.e., we do not find an increasing price-spread between the secondary market price and the net asset value per share after the introduction of the notice period.

\subsection{Breakpoint Estimation}

In the previous sections, the breakpoint for the segmented regressions was set to equal the regulatory change of April 5, 2011. In the following, we estimate the optimal breakpoint(s) endogenously from the data instead of exogenously specifying it as the date on which the minimum holding and notice periods were introduced.

Fig. 5 depicts the residual sum of squared errors for the estimated piecewise linear models with different daily breaks ranging from January 6, 2003 to October 18, 2017. Panel a shows the results for model (2) with the relative numbers of traded shares as the dependent variable. Panel b shows the results for model (4) with the pricespread as the dependent variable. 
A good fit for model (2), with the relative numbers of traded shares as the dependent variable, can be reached when the breakpoint is set to a day at the end of 2010. With a minimum residual sum of squared errors of 0.0183 , the optimal breakpoint is given for December 29, 2010. In comparison, for model (4) with the price-spread as the dependent variable, a good fit can be reached when the breakpoint is set to mid-2011. The lowest residual sum of squared errors is 5.3164 for a breakpoint on October 5, 2011.

The estimated residual sum of square curves supports the previous results that there is a structural break in the aftermath of the second liquidity crisis of OREFs. The reforming process for the regulation on OREFs began in 2010 and finally led to the revision of the law in April 2011. The coincidence of the structural break in the data and the reform date gives a strong indication that the minimum holding period together with the notice period has a structural effect on secondary market trading for OREF shares.

\section{Conclusion}

There is an extensive literature on the characteristics of OREFs and the liquidity crisis. However, the trading of OREF shares on the secondary market has not been discussed so far. The present paper provides a detailed analysis on the secondary market activities for OREF shares. We combine historical data on share prices and trading volumes from several stock exchanges in Germany with fund management announcements on fund liquidations and temporary issue or redemption suspensions.

We find that shares are traded on the secondary market, particularly when direct trading between investors and the fund management company is restricted. In the event that the fund management suspends the issue of additional shares, investors trade their shares on the secondary market at a potential premium, i.e., the secondary market price is higher than the net asset value per share. In the contrary event that the fund management suspends the redemption of shares, investors trade their shares at a substantial discount. Interestingly, shares of funds that are being liquidated are still traded on the secondary market, but at a substantial discount. Finally, we also find that the relative numbers of shares that are traded on the secondary market has increased since the introduction of the minimum holding and notice periods.

Our findings provide important information for investors and their financial advisors. Investors should consider the possibility that OREF shares may also be traded on the secondary market, even when direct trading with the fund management companies is suspended. The historical data shows that the secondary market price can be substantially above the net asset value per share, and shareholders can earn this premium should they sell their shares on the secondary market instead of redeeming them to the fund management company for the net asset value per share. In the exceptional event that redemption to the fund management is not possible, shareholders can still sell their shares on the secondary market, though at a potential discount. 
Acknowledgements We thank the conference participants at the European Real Estate Conference 2019. We are also grateful to Yannick Dillschneider, Arwed Ebner, and an anonymous referee for helpful comments and suggestions. Opinions and errors are solely those of the authors and not of the institutions with whom the authors are affiliated.

Open Access This article is licensed under a Creative Commons Attribution 4.0 International License, which permits use, sharing, adaptation, distribution and reproduction in any medium or format, as long as you give appropriate credit to the original author(s) and the source, provide a link to the Creative Commons licence, and indicate if changes were made. The images or other third party material in this article are included in the article's Creative Commons licence, unless indicated otherwise in a credit line to the material. If material is not included in the article's Creative Commons licence and your intended use is not permitted by statutory regulation or exceeds the permitted use, you will need to obtain permission directly from the copyright holder. To view a copy of this licence, visit http://creativecommons.org/licenses/by/4. $0 /$.

Funding This research was conducted with support from the German Investment and Asset Management Association (BVI).

Funding Open Access funding provided by Projekt DEAL.

\section{References}

Bannier, C.E., F. Fecht, and M. Tyrell. 2008. Open-End Real Estate Funds in Germany-Genesis and Crisis. Kredit und Kapital 41(1):9-36.

Barber, B. M., T. Odean, L. Zheng. 2005. Out of Sight, Out of Mind: The Effects of Expenses on Mutual Fund Flows. Journal of Business 78(6):2095-2120.

Barkham, R., and C. Ward. 1999. Investor sentiment and noise traders: Discount to net asset value in listed property companies in the UK. Journal of Real Estate Research 18(2):291-312.

Downs, D.H., S. Sebastian, C. Weistroffer, and R. O. Woltering. 2016. Real estate fund flows and the flowperformance relationship. Journal of Real Estate Finance and Economics 52(4):347-382.

Fecht, F., and M. Wedow. 2014. The dark and the bright side of liquidity risks: evidence from open-end real estate funds in Germany. Journal of financial intermediation 23(3):376-399.

Focke, C. 2006. The development of German open-ended real estate funds. Journal of Real Estate Literature 14(1):39-56.

Gil-Bazo, J., and P. Ruiz-Verdú (2009) The relation between price and performance in the mutual fund industry. Journal of Finance 64(5):2153-2183.

Huang, J., K. D. Wei, and H. Yan (2007) Participation costs and the sensitivity of fund flows to past performance. Journal of Finance 62(3):1273-1311.

Lee, C., A. Shleifer, and R. H. Thaler. 1991. Investor sentiment and the closed-end fund puzzle. Journal of Finance 46(1):75-109.

Maurer, R., F. Reiner, and R. Rogalla. 2004. Return and risk of German open-end real estate funds. Journal of Property Research 21(3):209-233.

Maurer, R., R. Rogalla, and Y. Shen. 2012. The liquidity crisis of German open-end real estate funds and their impact on optimal asset allocation in retirement. Zeitschrift für Betriebswirtschaft 82(1):79-107.

Schnejdar, S., M. Heinrich, R. O. Woltering, and S. Sebastian (2019) The Discount to NAV of Distressed Open-End Real Estate Funds. Journal of Real Estate Finance and Economics. https://doi.org/10.1007/ s11146-018-9694-8.

Sebastian, S. P., and M. Tyrell. 2006. Open End Real Estate Funds-Diamond or Danger? Goethe University Working Paper Series: Finance and Accounting, Vol. 168.

Weistroffer, C., and S. Sebastian (2015) The German open-end fund crisis—a valuation problem? Journal of Real Estate Finance and Economics 50(4):517-548.

Publisher's Note Springer Nature remains neutral with regard to jurisdictional claims in published maps and institutional affiliations. 